\title{
Effects of toasting and decortication of oat on nutrient digestibility in the rumen and small intestine and on amino acid supply in dairy cows
}

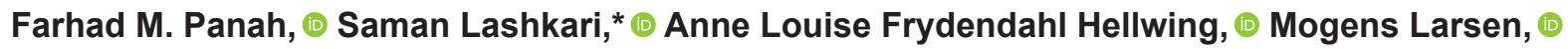 \\ and Martin Riis Weisbjerg $\odot$ \\ Department of Animal Science, Aarhus University, AU Foulum, PO Box 50, 8830 Tjele, Denmark
}

\begin{abstract}
This study examined the potential for decorticating and toasting of oat (Avena sativa) to supply crude protein $(\mathrm{CP})$ and amino acids (AA) in dairy cows. Four lactating Danish Holstein Friesian cows fitted with ruminal, duodenal, and ileal cannulas were assigned to a $4 \times 4$ Latin square design. Cows were fed experimental diets ad libitum based on grass-clover silage and toasted fava beans, with oat included in different forms arranged in a $2 \times 2$ factorial: whole oat, decorticated oat, toasted oat, and decorticated toasted oat. In situ rumen degradability of processed oat was also evaluated. Decortication increased starch intake by $0.38 \mathrm{~kg} / \mathrm{d}$ and reduced NDF intake by $0.91 \mathrm{~kg} / \mathrm{d}$. Toasting reduced ruminal AA digestibility and increased duodenal flow of $\mathrm{CP}$ by $0.41 \mathrm{~kg} / \mathrm{d}$. In situ degradation rate and effective degradability of $\mathrm{CP}$ in the rumen were reduced by 0.46 $\mathrm{h}^{-1}$ and $310 \mathrm{~g} / \mathrm{kg} \mathrm{CP}$ due to toasting. Both decortication and toasting increased microbial synthesis of $\mathrm{CP}$ by 0.20 and $0.41 \mathrm{~kg} / \mathrm{d}$, respectively. Decortication and toasting did not affect small intestinal AA digestibility, but did increase the total digested amount of AA by 154 and $250 \mathrm{~g} / \mathrm{d}$, respectively. Milk production was not affected by treatments. Methane production (L/d) decreased with decortication and toasting. In conclusion, unless an interaction exists between decortication and toasting, the results indicate additive effects of toasting and decorticating oat for increasing the supply of digestible AA to the small intestine of dairy cows.
\end{abstract}

Key words: dehulling, toasting, oat, amino acid, $\mathrm{CH}_{4}$ emission, microbial synthesis

\section{INTRODUCTION}

Within the European Union, organic milk production almost doubled from 2007 to 2016 (Willer et al., 2019), and in Denmark, it reached $11.0 \%$ of total milk produc-

Received June 22, 2019.

Accepted October 23, 2019.

*Corresponding author: Saman.L@anis.au.dk tion in 2017 (Danish Agriculture and Food Council, 2019). Organic dairying is associated with low external input, such as restricted use of concentrate (BlancoPenedo et al., 2012; Scollan et al., 2017) and, based on the European organic farming regulation No. 889/2008 (January 2008), preferably using feedstuffs grown on the farm or obtained from local sources. These factors might limit farmers' options for supplementing their cows with sufficient MP to obtain a high production level. Hence, optimizing the supply of MP via homegrown cereals high in $\mathrm{CP}$ or increasing the protein value through processing is needed for more efficient organic milk production.

Oat has fairly high concentrations of $\mathrm{CP}$ (Biel et al., 2009) and crude fat (Decker et al., 2014; Qi et al., 2017). The hull of oat (Avena sativa) constitutes 28 to $32 \%$ of the grain DM, and due to the presence of lignin-carbohydrate/phenolic-carbohydrate complexes (Decker et al., 2014), hulls have very low degradability in the rumen (Garleb et al., 1991). Thus, due to low concentrations of $\mathrm{CP}$ and crude fat in the hull (Salo and Kotilainen, 1970), decortication could be a potential processing method to increase the content of $\mathrm{CP}$ and crude fat in oat grain.

Synthesized microbial CP is not solely sufficient for fulfilling the protein requirement in high-yielding dairy cows (Savari et al., 2018). Thus, applying heat treatment (e.g., toasting) could be a possible way to reduce ruminal degradation of CP (Kung and Rode, 1996). Heat treating the cereals causes a Maillard reaction between carbonyl groups of reducing sugars and free $\varepsilon$-amino groups of proteins (Oste et al., 1986). McNiven et al. (1995), Lund et al. (2004), and Lashkari et al. (2015) implemented heat treatment to manipulate the site of digestion in the rumen and thereby increase the supply of dietary nutrients in the duodenum.

Methane is a potent greenhouse gas, and organic dairy farms are associated with more $\mathrm{CH}_{4}$ production per kilogram of fermentable $\mathrm{OM}$ than conventional ones. This greater $\mathrm{CH}_{4}$ production is mainly due to the higher forage:concentrate ratio, at least up to $60 \%$ forage, in organic dairying (Fall et al., 2008). Decreasing 
Table 1. Total mixed ration and nutrient composition of experimental diets $(\mathrm{g} / \mathrm{kg}$ of $\mathrm{DM}$ unless otherwise noted)

\begin{tabular}{lcccc}
\hline & \multicolumn{3}{c}{ Diet $^{1}$} \\
\cline { 2 - 5 } Item & Oat & $\mathrm{D}$ & $\mathrm{T}$ & $\mathrm{DT}$ \\
\hline Ingredient & & & - & - \\
Whole oat grain & 217.1 & - & - & - \\
Decorticated oat grain & - & 217.1 & 217.1 & 217.1 \\
Toasted oat grain & - & - & - & 165.2 \\
Decorticated toasted oat grain & 165.2 & 165.2 & 165.2 & 809 \\
Toasted fava beans & 609 & 609 & 609 & 8.70 \\
Grass clover silage & 8.70 & 8.70 & 8.70 & 561 \\
Mineral supplements & 540 & 540 & 563 & 47.4 \\
Nutrient & 77.6 & 77.4 & 77.8 & 198 \\
DM, g/kg & 43.9 & 48.1 & 40.5 & 174 \\
Ash & 194 & 197 & 193 & 301 \\
Crude fat & 156 & 175 & 151 & 331 \\
CP & 331 & 310 & & \\
Starch & & & \\
NDF &
\end{tabular}

${ }^{1} \mathrm{D}=$ decorticated oat; $\mathrm{T}=$ toasted oat; $\mathrm{DT}=$ decorticated and toasted oat.

the fiber content and increasing the starch content in the diet are well-known strategies to reduce enteric $\mathrm{CH}_{4}$ production by cows because $\mathrm{CH}_{4}$ produced per digested unit is lower for starch than for fiber (Moe and Tyrrell, 1979; Brask et al., 2015).

Our study hypotheses were that decortication would increase protein, fat, and digestible $\mathrm{OM}$ intake and decrease the enteric $\mathrm{CH}_{4}$ production per kilogram of DM intake, and that toasting would increase MP intake. Therefore, the objective of this study was to document the effect of decortication and toasting of oat on nutrient digestibility in rumen and small intestine, protein and AA supply in dairy cows, and enteric $\mathrm{CH}_{4}$ production.

\section{MATERIALS AND METHODS}

\section{Animal and Experimental Design}

This experiment complied with the ethical requirements delineated in the Danish Ministry of Justice Law No. 726 (September 9, 1993). Two primiparous and 2 multiparous lactating Danish Holstein dairy cows were fitted with rumen cannulas (\#4C; Bar Diamond, Parma, ID) and duodenal and ileal simple polyvinyl chloride T-cannulas (i.d. $=2.5 \mathrm{~cm}$ ) placed $60 \mathrm{~cm}$ caudal to the pylorus (duodenal) and $20 \mathrm{~cm}$ cranial to the cecum (ileum). Cows were fed 1 of 4 experimental diets in a $4 \times 4$ Latin square design. Animals were housed in tie-stalls, and beds were covered with mattresses and sawdust. At the start of the experiment, the average $\mathrm{BW}$ was $618 \pm 47.9 \mathrm{~kg}$ (mean $\pm \mathrm{SD}$ ), the cows were at $61.3 \pm 49.9 \mathrm{DIM}$, and their BCS was $3 \pm 0.20$. The processing methods, decortication and toasting, were investigated in a $2 \times 2$ factorial arrangement of treatments (Table 1). The experimental diets were TMR containing whole-grain oat (oat), decorticated oat (D), toasted whole oat $(\mathbf{T})$, or decorticated toasted oat (DT) as the grain source. All 4 types of oats were rolled weekly before use in the ration. Days 1 to 13 served as the adaptation period, and collection of digesta (i.e., rumen, duodenum, ileum, feces) was carried out from d 13 to 17 . On d 17 to 22 the enteric $\mathrm{CH}_{4}$ emission was measured in respiration chambers.

\section{Feeds, Diet, and Feeding}

The oat variety used in this experiment was Dominik, and it was grown in Denmark in 2017. Decortication was conducted using a mobile decorticator with 3 Bühler huller MHSA (Bühler AG, Uzwil, Switzerland) mounted on a truck. Decortication was performed on farm by Gl. Buurholt ApS (Brønderslev, Denmark) with an efficacy of $83 \%$; the remainder was either partially decorticated or intact. Toasting was performed on farm using a Bulldog Toaster (Mecmar S.p.a., Minerbe, Italy) at $121^{\circ} \mathrm{C}$. The flow through the toaster was 2,500 $\mathrm{kg} / \mathrm{h}$, and the retention time was $35 \mathrm{~s}$. The chemical composition of the ration feedstuffs is shown in Table 2. Samples of all ingredients were taken in each period. The samples taken in periods 1 and 2 were pooled to one sample, and those taken in periods 3 and 4 were pooled to one sample, before the samples were sent for chemical analysis.

The rations were formulated according to NorFor (Volden, 2011). Rations were similar except for the oat portion, which made up $217 \mathrm{~g} / \mathrm{kg}$ of ration DM (Table 2 ). The forage:concentrate ratio of the TMR was 60:40 
on a DM basis. The TMR consisted of grass-clover silage, toasted fava beans ground on a disc mill, vitamin and mineral supplements, and either oat, decorticated oat, toasted oat, or decorticated toasted oat (Table 2). Cows were fed ad libitum with TMR twice a day (0600 and $1630 \mathrm{~h}$ ). The feed was mixed once daily before the afternoon feeding. Feed offered and the residues were recorded daily, and the DM concentration of feed and residues was determined on d 12 to 21 in each period. Water was provided ad libitum, and consumption was recorded using water meters.

\section{Rumen, Digesta, and Feces Sampling}

Chromic oxide $\left(\mathrm{Cr}_{2} \mathrm{O}_{3}\right)$ and titanium dioxide $\left(\mathrm{TiO}_{2}\right)$ were used as digestion markers. Ten grams of $\mathrm{Cr}_{2} \mathrm{O}_{3}$ and $13 \mathrm{~g}$ of $\mathrm{TiO}_{2}$ in disintegrable bags were placed into the rumen twice a day at milking. Rumen liquid, intestinal chyme, and feces were sampled 12 times over $5 \mathrm{~d}$ (i.e., d 13-17) at 1000 and $1800 \mathrm{~h}$ (d 13); 0200, 1200, and 2000 $\mathrm{h}$ (d 14); 0400, 1400, and $2200 \mathrm{~h}$ (d 15); 0600, 1600, and 2400 h (d 16); and 0800 h (d 17). Rumen liquid was sampled from the ventral rumen using a 90-cm steel rumen sampler (Bar Diamond Inc.) with an attached 50 - $\mathrm{mL}$ syringe.

Duodenal $(0.5 \mathrm{~L})$ and ileal $(0.2 \mathrm{~L})$ samples were collected from the T-cannula. Feces (approximately $50 \mathrm{~g}$ ) was sampled during defecation or by grab sampling from the rectum. The 12 samples for duodenal and ileal contents and feces were pooled.

Rumen liquid samples were analyzed for $\mathrm{pH}$ directly after sampling using a digital $\mathrm{pH}$ meter (Meterlab PHM 220, Radiometer, Brønshøj, Denmark). Rumen microbes were harvested on d 17 at $1200 \mathrm{~h}$. Two liters of rumen liquid were collected with a cup and filtered through 2 layers of cheesecloth into prewarmed thermos bottles and immediately transferred to the laboratory. Feed particles and protozoa were removed by centrifuging twice at $500 \times g$ for $5 \mathrm{~min}$ at $3^{\circ} \mathrm{C}$. Next, the supernatant was centrifuged at $17,300 \times g$ for $20 \mathrm{~min}$ at $3^{\circ} \mathrm{C}$. The pellet was resuspended in $200 \mathrm{~mL}$ of saline solution $(0.9 \% \mathrm{NaCl})$ and centrifuged at $17,300 \times g$ for 20 min at $3^{\circ} \mathrm{C}$, after which the pellet (microbial matter) was harvested.

Table 2. Chemical composition of feedstuffs (means $\pm \mathrm{SD} ; \mathrm{g} / \mathrm{kg}$ of DM unless otherwise noted)

\begin{tabular}{|c|c|c|c|c|c|c|c|}
\hline & \multicolumn{6}{|c|}{ Feedstuff } & \multirow[b]{2}{*}{$\begin{array}{l}\text { Oat } \\
\text { hull }^{1}\end{array}$} \\
\hline & $\begin{array}{l}\text { Grass-clover } \\
\text { silage }\end{array}$ & $\begin{array}{c}\text { Toasted } \\
\text { fava beans }\end{array}$ & Oat & $\begin{array}{c}\text { Decorticated } \\
\text { oat }\end{array}$ & $\begin{array}{c}\text { Toasted } \\
\text { oat }\end{array}$ & $\begin{array}{c}\text { Decorticated } \\
\text { toasted oat }\end{array}$ & \\
\hline $\mathrm{DM}, \mathrm{g} / \mathrm{kg}$ of fresh matter & $302 \pm 0.84$ & $946 \pm 0.95$ & $882 \pm 0.74$ & $881 \pm 1.39$ & $986 \pm 1.14$ & $975 \pm 1.43$ & 946 \\
\hline Ash & $95.2 \pm 0.20$ & $38.0 \pm 0.24$ & $21.6 \pm 0.04$ & $20.5 \pm 0.04$ & $22.1 \pm 0.08$ & $20.5 \pm 0.10$ & 25.6 \\
\hline $\mathrm{CP}$ & $192 \pm 1.44$ & $294 \pm 1.33$ & $91.0 \pm 0.13$ & $107 \pm 0.38$ & $87.9 \pm 0.46$ & $109 \pm 0.07$ & 58.1 \\
\hline Buffer solubility, $\mathrm{g} / \mathrm{kg}$ of $\mathrm{CP}$ & $627 \pm 8.06$ & $198 \pm 3.01$ & $206 \pm 4.86$ & $256 \pm 47.5$ & $105 \pm 12.6$ & $94.9 \pm 0.41$ & 247 \\
\hline $\mathrm{OMD}^{3}$ & $789 \pm 8.10$ & $865 \pm 0.0$ & $690 \pm 7.05$ & $830 \pm 9.50$ & $695 \pm 2.45$ & $823 \pm 0.31$ & NA \\
\hline Starch & NA & $304 \pm 0.21$ & $449 \pm 1.75$ & $535 \pm 1.36$ & $422 \pm 1.53$ & $530 \pm 3.51$ & 221 \\
\hline Total AA & $134 \pm 3.48$ & $250 \pm 2.55$ & $74.0 \pm 2.22$ & $88.5 \pm 1.55$ & $68.4 \pm 0.96$ & $86.9 \pm 0.65$ & NA \\
\hline \multicolumn{8}{|l|}{ Amino acids, $\mathrm{g} / \mathrm{kg}$ of $\mathrm{AA}$} \\
\hline Ala & $91.3 \pm 6.71$ & $47.6 \pm 0.07$ & $53.3 \pm 0.43$ & $52.7 \pm 0.09$ & $55.1 \pm 0.22$ & $54.7 \pm 0.18$ & NA \\
\hline Arg & $23.6 \pm 0.32$ & $98.9 \pm 0.42$ & $72.3 \pm 0.45$ & $74.2 \pm 0.31$ & $69.0 \pm 0.05$ & $67.3 \pm 0.19$ & NA \\
\hline Asp & $135 \pm 4.83$ & $121 \pm 0.02$ & $86.5 \pm 0.40$ & $85.4 \pm 0.01$ & $88.5 \pm 0.28$ & $87.9 \pm 0.24$ & NA \\
\hline Leu & $93.3 \pm 1.11$ & $84.1 \pm 0.30$ & $81.1 \pm 0.11$ & $80.7 \pm 0.53$ & $82.0 \pm 0.04$ & $82.6 \pm 0.92$ & $\mathrm{NA}$ \\
\hline Lys & $48.1 \pm 2.87$ & $70.4 \pm 0.09$ & $47.8 \pm 1.88$ & $46.2 \pm 0.03$ & $36.6 \pm 0.01$ & $32.9 \pm 0.22$ & NA \\
\hline Met & $19.6 \pm 0.30$ & $8.37 \pm 0.05$ & $20.3 \pm 0.02$ & $20.4 \pm 0.04$ & $20.0 \pm 0.03$ & $19.6 \pm 0.02$ & NA \\
\hline Phe & $52.5 \pm 0.71$ & $47.7 \pm 0.16$ & $53.3 \pm 0.14$ & $53.5 \pm 0.27$ & $54.5 \pm 0.004$ & $55.0 \pm 0.34$ & NA \\
\hline Pro & $98.0 \pm 4.58$ & $46.1 \pm 0.16$ & $57.3 \pm 0.19$ & $57.0 \pm 1.02$ & $57.6 \pm 0.87$ & $57.1 \pm 0.53$ & $\mathrm{NA}$ \\
\hline Ser & $53.3 \pm 1.95$ & $56.7 \pm 0.20$ & $57.1 \pm 0.85$ & $57.0 \pm 0.18$ & $57.6 \pm 0.47$ & $57.4 \pm 0.45$ & NA \\
\hline Thr & $54.4 \pm 0.77$ & $40.6 \pm 0.11$ & $38.9 \pm 0.38$ & $38.6 \pm 0.13$ & $39.6 \pm 0.27$ & $39.1 \pm 0.12$ & NA \\
\hline Val & $77.5 \pm 0.75$ & $54.4 \pm 0.94$ & $58.8 \pm 1.09$ & $58.1 \pm 0.12$ & $59.4 \pm 0.12$ & $60.4 \pm 1.56$ & $\mathrm{NA}$ \\
\hline
\end{tabular}

${ }^{1}$ Samples of obtained hulls are for comparison and hulls were not used in diets.

${ }^{2} \mathrm{NA}=$ not analyzed.

${ }^{3} \mathrm{In}$ vivo $\mathrm{OM}$ digestibility (OMD) based on in vitro OM digestibility of silage and concentrate. 


\section{In Situ Study}

Rumen in situ CP degradation of the 4 tested oats and a hull sample was determined according to the standard NorFor procedure (Åkerlind et al., 2011). Dacron bags $(7 \times 6 \mathrm{~cm}, 38-\mu \mathrm{m}$ pore size $)$ were filled with approximately $1 \pm 0.01 \mathrm{~g}$ of ground $(1.5-\mathrm{mm})$ sample and $12 \mathrm{mg} / \mathrm{cm}^{2}$ sample-to-surface area ratio (Nocek, 1988). The bags were incubated in the rumen of 3 dry cows fed at maintenance level for $0,2,4,8,24,48$, and $96 \mathrm{~h}$. After rumen incubation, all bags were rinsed in running cold water and subsequently washed using a domestic washing machine for 10 min using $2 \times 22 \mathrm{~L}$ of water $\left(25^{\circ} \mathrm{C}\right)$. Residues were then transferred to $\mathrm{N}$-free filter paper (retention value 2, Whatman AGF 607-90 $\mathrm{mm})$ for $\mathrm{DM}\left(103^{\circ} \mathrm{C}\right)$ and $\mathrm{N}$ analysis (Kjeldahl). Water solubility was estimated over filter paper as described by Hvelplund and Weisbjerg (2000). Particle loss was determined as the difference between the loss from the nylon bags when they were only washed and the water solubility measured on filter paper (Hvelplund and Weisbjerg, 2000).

Total-tract disappearance (TTD) was determined using the mobile bag technique according to Hvelplund et al. (1992). The Dacron bags $(6 \times 6 \mathrm{~cm}, 12-\mu \mathrm{m}$ pore size) were sealed after loading $1.0 \pm 0.01 \mathrm{~g}$ of the samples. Bags were ruminally pre-incubated using 3 dry cows for $16 \mathrm{~h}$, as described above. In each cow, 2 replicates of each sample were incubated (6 observations for each treatment). Bags were incubated in $\mathrm{HCl}$ (pH 2.4) for $1 \mathrm{~h}$ and subsequently incubated for $2 \mathrm{~h}$ in pepsin- $\mathrm{HCl}$ solution (200 $\mathrm{mg}$ of pepsin dissolved in $2 \mathrm{M} \mathrm{HCl}$ ) at $40^{\circ} \mathrm{C}$ in a Daisy incubator with rotation (Ankom, Macedon, NY) to simulate abomasal digestion. Thereafter, the bags were inserted into the small intestine of 2 lactating cows through the duodenal cannula (open T-piece placed $60 \mathrm{~cm}$ caudal to the pylorus). After fecal recovery, bags were machine-washed as mentioned above, and residues were transferred to $\mathrm{N}$-free filter paper using the same procedure as for rumen bags to determine the total-tract $\mathrm{CP}$ disappearance.

\section{Gas Exchange Measurement}

Gas exchange was measured (d 17-22) by means of open-circuit indirect calorimetry using 4 respiration chambers according to Hellwing et al. (2012). The chambers were positioned in a square in the same barn where the collection of digesta took place. To balance out any possible differences in inlet air composition, the cows were switched between the chambers diagonally, after 3 of the $5 \mathrm{~d}$ of measurements. Gas concentrations of inlet and outlet air and flow in each of the 4 chambers $\left(\mathrm{CH}_{4}, \mathrm{CO}_{2}, \mathrm{O}_{2}\right.$, and $\left.\mathrm{H}_{2}\right)$ were measured every 12.5 min as described by Hellwing et al. (2012). Calculations for gas exchange were based on standard conditions for temperature and pressure $\left(0^{\circ} \mathrm{C}\right.$ and $\left.101.325 \mathrm{kPa}\right)$. The recovery $(\% \pm \mathrm{SD})$ of $\mathrm{CH}_{4}$ and $\mathrm{CO}_{2}$ gases measured at chamber level was $99.5 \pm 0.4 \%$ and $99.9 \pm 0.3 \%$. For other gases, the average recovery of $\mathrm{CH}_{4}$ and $\mathrm{CO}_{2}$ was assumed $(99.7 \%)$.

\section{Chemical Analysis}

All feed and digesta samples were stored frozen at $-20^{\circ} \mathrm{C}$ and subsequently freeze-dried before laboratory analysis. Dry matter was determined by ovendrying at $60^{\circ} \mathrm{C}$ for $48 \mathrm{~h}$ (A kerlind et al., 2011). The ash content was determined by combustion at $525^{\circ} \mathrm{C}$ for $6 \mathrm{~h}$. The Dumas method (Hansen, 1989) was used to determine the nitrogen content of feed, digesta, and microbial matter using a Vario MAX CN (Elementar Analysesysteme GmbH, Hanau, Germany). Nitrogen in bag residues from rumen degradation and from mobile bags was analyzed using the Kjeldahl method, and $\mathrm{CP}$ was calculated as $\mathrm{N}$ times 6.25. Soluble $\mathrm{N}$ in samples was analyzed by extraction in a boratephosphate buffer ( $\mathrm{pH} 6.75$ ) at $39^{\circ} \mathrm{C}$ for $1 \mathrm{~h}$ according to Åkerlind et al. (2011). Crude fat was determined using a Soxhlet apparatus with petroleum ether extraction after $3 \mathrm{M} \mathrm{HCl}$ hydrolysis (Stoldt, 1952). Starch concentration of feedstuffs was determined by an enzymatic colorimetric method (Bach Knudsen et al., 1987). In this method, $150 \mathrm{mg}$ of the ball-milled grains (approximately $100 \mathrm{mg}$ starch) was weighed into 50-mL centrifuge tubes with screw caps. Heatstable $\alpha$-amylase and acetate buffer $(0.1 \mathrm{M}, \mathrm{pH} 5.0,40$ $\mathrm{mL}$ ) were added, and the mixture was then incubated for $1 \mathrm{~h}$ at $100^{\circ} \mathrm{C}$. To extend the breakdown of released oligosaccharides to glucose monomers a further incubation of the samples with an amyloglucosidase from Aspergillus oryzae for $2 \mathrm{~h}$ at $60^{\circ} \mathrm{C}$ was done. The tubes were centrifuged $(3,000 \times g, 10 \mathrm{~min})$, and after dilution $(500 \mu \mathrm{L}$ to $100 \mathrm{~mL})$, the released glucose monomers in the supernatant were measured with a glucose oxidase reagent. The factor 0.9 was then used to convert the values for glucose to the equivalent starch polysaccharide. The NDF concentration was analyzed according to Mertens (2002) method in a Fibertec M6 System (Foss Analytical, Hillerød, Denmark) using sodium sulfite and heat-stable amylase treatments and corrected for residual ash.

In vitro OM digestibility (IVOS) of silage in the basal diet was determined according to Tilley and Terry (1963) by incubating samples in rumen fluid for $48 \mathrm{~h}$, followed by a $48-\mathrm{h}$ digestion by pepsin and $\mathrm{HCl}$. Incubation residues were then combusted to determine OM digestibility. 
In vitro enzyme digestible OM (EDOM) for concentrate was measured by treating the samples with a pepsin- $\mathrm{HCl}$ solution for $24 \mathrm{~h}$, after which the samples were heated at $80^{\circ} \mathrm{C}$ for $45 \mathrm{~min}$. After washing, the residues were treated with an enzyme mixture for 24 $\mathrm{h}$ at $40^{\circ} \mathrm{C}$ and then incubated for $19 \mathrm{~h}$ at $60^{\circ} \mathrm{C}$. The enzyme mixture consisted of $20 \mathrm{~mL}$ of Celluclast 1.5 L (EC 232-734-4; Novozymes Inc., Copenhagen, Denmark), $10 \mathrm{~mL}$ of Viscozym L from Novozymes Inc., $2.175 \mathrm{~g}$ of amyloglycosidase (EC 3.2.1.3, 3,200 U/mL), $17.0 \mathrm{~mL}$ Novozym 51054 from Novozymes Inc., and $0.1 \mathrm{~g}$ of chloramphenicol (EC 200-287-4) with $800 \mathrm{~mL}$ of acetate buffer $(\mathrm{pH} 4.8 \pm 0.1)$. The acetate buffer consisted of $8.16 \mathrm{~g}$ of sodium acetate (EC 204-823-8) dissolved in $0.5 \mathrm{~L}$ of water and $7.5 \mathrm{~mL}$ of acetic acid (30\% wt/wt $5.8 \mathrm{M}$, EC 200-580-7) and water added to $1 \mathrm{~L}$. Residues were washed and acetone extracted before determination of undigested residues (Weisbjerg and Hvelplund, 1993).

Ammonia in rumen liquid was alkalinized with potassium hydroxide followed by distillation and titration using a Kjeltec 2400 (Foss Analytical; Brask et al., 2013a). Volatile fatty acids of rumen fluid were analyzed by gas chromatography as described by Kristensen et al. (1996). Glucose and L-lactate were determined with membrane-immobilized substrate-specific oxidases using an YSI 2900 Biochemistry Analyzer (YSI Inc., Yellow Springs, $\mathrm{OH}$ ). Chromic oxide in digesta and feces was oxidized to chromate and determined colorimetrically (Schürch et al., 1950). Titanium dioxide was digested with sulfuric acid, hydrogen peroxide was added, and absorbance was measured spectrophotometrically according to Myers et al. (2004), with the modification that $15 \mathrm{~mL}$ of $30 \%$ hydrogen peroxide was added instead of $10 \mathrm{~mL}$ and an additional 5 drops were added before the absorbance was measured. Microbial matter and duodenal chyme were analyzed for total purine content by the method of Zinn and Owens (1986) as modified by Thode (1999). Briefly, the nucleotides were hydrolyzed by the addition of perchloric acid, after which purines precipitated into complexes with silver nitrate and were measured spectrophotometrically.

Amino acids were determined using the EEC (98/64/ EC) method (European Commission, 1998). Samples were oxidized with performic acid followed by hydrolysis with $\mathrm{HCl}$, and individual AA were subsequently determined on a Biochrom B20 automated AA analyzer. Isoleucine, Ser, and Val were corrected to account for incomplete recovery, using a factor of 1.06 (Rudemo et al., 1980).

Fat, protein, and lactose (monohydrate) concentrations in milk were determined by an infrared analyzer (Milkoscan Msc4000, Foss Analytical) at Eurofins Steins Laboratories (Vejen, Denmark).

\section{Calculations and Statistical Analysis}

Data on gas exchange, DMI, water intake, and milk yield and composition were averaged per cow per period. Digesta DM flows were calculated as average of flows for each marker. Microbial net synthesis (flow to the duodenum) was calculated according to Lund et al. (2003), using the concentration of nitrogen and purines in rumen-isolated bacteria, the concentration of purines in duodenal contents, and duodenal DM flow. The calculation of microbial efficiency was expressed as the amount of microbial $\mathrm{CP}$ synthesized relative to the true rumen digested $\mathrm{OM}(\mathrm{g} \mathrm{CP} / \mathrm{kg}$ true rumen digested OM; Lund et al., 2003). The amount of true rumen digested OM was calculated by subtracting duodenal OM flow (corrected for duodenal microbial OM flow) from OM intake.

The predicted in vivo OMD of grass-clover silage was calculated based on Møller et al. (1989), according to the following equation:

$$
\mathrm{OMD}=41.0+0.959 \times \mathrm{IVOS}
$$

where OMD is the calculated in vivo digestibility of $\mathrm{OM}(\mathrm{g} / \mathrm{kg}$ of $\mathrm{OM})$. In vivo OMD for concentrate was calculated by the equation suggested by Weisbjerg and Hvelplund (1993):

$$
\mathrm{OMD}=53.8+0.867 \times \mathrm{EDOM},
$$

where OMD is the calculated in vivo digestibility of $\mathrm{OM}(\mathrm{g} / \mathrm{kg}$ of $\mathrm{OM})$.

Energy-corrected milk yield $(3.14 \mathrm{MJ} / \mathrm{kg})$ was calculated using the following formula: $\mathrm{ECM}=$ milk yield $\times(383 \times$ milk fat $+242 \times$ milk protein $+157.1 \times$ milk lactose +20.7$) / 3,140$ (Sjaunja et al., 1990), where lactose is lactose monohydrate, and milk fat, protein, and lactose are expressed as the daily yield $(\mathrm{kg} / \mathrm{d})$.

Degradability of $\mathrm{CP}$ was fitted in a nonlinear least square model to the equation Deg $(t)=a+b\left(1-\mathrm{e}^{-c t}\right)$ (Ørskov and McDonald 1979). Here, Deg $(t)$ is the fraction of CP degraded at time $t$ of incubation (h), $a$ is the immediately degradable (soluble) fraction at $0 \mathrm{~h}$ of incubation, $b$ is the fraction not soluble but potentially degradable depending on time, and $c\left(\mathrm{~h}^{-1}\right)$ is the degradation rate of the fraction $b$. Effective degradability (ED) in the rumen was calculated according to Ørskov and McDonald (1979) using $0.08 \mathrm{~h}^{-1}$ rumen fractional passage rate $(k)$ in the following equation: $\mathrm{ED}=a+$ $b[c /(c+k)]$.

The small intestinal disappearance (SID, g/ $/ \mathrm{kg}$ ) of $\mathrm{CP}$ escaping ruminal degradation was calculated based on ED and TTD (Hvelplund et al., 1992): SID = (TTD - ED)/(1,000 - ED). 
Data were analyzed in R (R Core Team, 2018), using the Fit Linear Mixed-Effects Models (LMM) procedure through the "lmer" function in "Ime4" package (Bates et al., 2014). The following model was used for in vivo data:

$$
Y_{i j k l}=\mu+D_{i}+T_{j}+D T_{i j}+P_{k}+C_{l}+E_{i j k l},
$$

where $Y$ is the dependent variable, $\mu$ is the overall mean, and the model includes the fixed effects of decortication $\left(D_{i}\right)$, toasting $\left(T_{j}\right)$, the interaction $\left(D T_{i j}\right)$, the $k$ th period $\left(P_{k}\right)$, and the random effect of $l$ th cow $\left(C_{l}\right)$. $E_{i j k l}$ is the random error.

The main effect of decortication and toasting is reported in full terms; that is, decortication refers to the main effect of decortication in D and DT diets, and toasting refers to the main effect of toasting in $\mathrm{T}$ and DT diets. Further, diurnal variations in rumen parameters were assessed by a mixed model as above, including time as an independent repeated measurement.

The parameters for the in situ study were analyzed using the LMM procedure in R:

$$
Y_{i j k}=\mu+D_{i}+T_{j}+D T_{i j}+C_{k}+E_{i j k},
$$

where $Y$ is the dependent variable; $\mu$ is the overall mean; decortication $\left(D_{i}\right)$, toasting $\left(T_{j}\right)$, and the interaction $\left(D T_{i j}\right)$ are fixed effects; the effect of $k$ th cow $\left(C_{k}\right)$ is random; and $E_{i j k}$ is the random error.

Values presented in Tables 3-9 and Supplemental Tables S1-S4 (https://doi.org/10.3168/jds.2019-17142) are least squares means with corresponding standard error of means. Significance was declared at $P<0.05$ and a tendency at $0.05<P<0.10$. When significant interactions were found, least squares means were compared using Tukey-Kramer test in $\alpha=0.05$. Unless there is interaction between decortication and toasting, the results indicate that main effects are additive.

\section{RESULTS}

\section{Composition of Experimental Feeds}

Decortication (the difference between decorticated oats and undecorticated oats) increased the concentration of CP, starch, and crude fat by 18.6, 97.0, and 20.3 $\mathrm{g} / \mathrm{kg}$ of DM, and it decreased the NDF concentration by $115 \mathrm{~g} / \mathrm{kg}$ of DM compared with the oat (Table 2). Digestibility (OMD) estimated by an in vitro enzymatic method was considerable higher for the decorticated oat. In addition, total AA concentration was highest in decorticated oat, and the Lys proportion of total AA was lower for decorticated oat than for oat. Toasted oat had lower solubility of CP and lower crude fat concentration. The composition of the removed hull mirrored the difference between oat and decorticated hull, with lower $\mathrm{CP}$ and starch and higher NDF concentration in hulls than in oat (Table 2).

\section{Intake, Digested Nutrients, and Digestion}

Compared with untreated oat, decortication increased $(P=0.01)$ starch intake by $0.38 \mathrm{~kg} / \mathrm{d}$ and reduced $(P=0.01) \mathrm{NDF}$ intake by $0.91 \mathrm{~kg} / \mathrm{d}$. Dry matter and OM intake tended $(P=0.08)$ to be increased by toasting (Table 3). Decortication increased $(P=0.02)$ the ruminal digested amount of starch by $0.29 \mathrm{~kg} / \mathrm{d}$ and increased the digested amount of starch in the small intestine $(P<0.01)$ and in the total tract $(P<0.01)$. Decortication lowered $(P=0.05)$ the digested amount of NDF in the rumen by $0.79 \mathrm{~kg} / \mathrm{d}$. Toasting decreased $(P=0.05)$ the digested amount of $\mathrm{CP}$ in the rumen by $0.28 \mathrm{~kg} / \mathrm{d}$ and increased $(P=0.04)$ the amount digested in the small intestine by $0.35 \mathrm{~kg} / \mathrm{d}$. Toasting also decreased $(P=0.02)$ the digested amount of AA in the rumen and decortication tended $(P=0.09)$ to decrease it. The amount of digested AA in the small intestine increased by 0.15 and $0.26 \mathrm{~kg} / \mathrm{d}$ due to decortication $(P=0.02)$ and toasting $(P<0.01)$, respectively. Decortication decreased $(P<0.01)$ the proportion of Lys and it increased $(P<0.01)$ the proportion of Met in AA intake (Supplemental Table S1; https://doi.org/10 $.3168 /$ jds.2019-17142). Moreover, toasting reduced ( $P$ $<0.01)$ the proportion of Lys, His, and Met in AA intake. Both decortication and toasting increased the digested amount $(\mathrm{g} / \mathrm{d})$ of Lys and Met in small intestine (Supplemental Table S2; https://doi.org/10.3168/ jds.2019-17142). Ruminal digestibility of Arg, Asp, Cys, Glu, Lys, Phe, Pro, Ser, and Val was reduced ( $P$ $\leq 0.05$ ) by toasting (Supplemental Table S3; https:// doi.org/10.3168/jds.2019-17142).

Toasting decreased $(P=0.03)$ the concentration of $\mathrm{CP}$ and AA in microbial DM (Table 4). Toasting also decreased $(P \leq 0.05)$ the proportion of Arg and Glu, whereas it increased $(P=0.01)$ Gly in microbial AA $(\mathrm{g} / \mathrm{kg}$ AA). Decortication tended to decrease $(P=$ $0.07)$ the proportion of Ile, and it increased $(P=0.05)$ Ser. Both decortication and toasting increased $(P<$ $0.01)$ the daily microbial OM flow $(\mathrm{kg} / \mathrm{d})$ by $0.29 \mathrm{~kg} / \mathrm{d}$. Decortication and toasting also increased $(P=0.01)$ the duodenal flow of microbial $\mathrm{CP}$ by 0.17 and 0.15 $\mathrm{kg} / \mathrm{d}$ and microbial AA flow at the duodenum by 0.12 and $0.13 \mathrm{~kg} / \mathrm{d}$ on average, respectively. Decortication increased $(P=0.03)$ microbial efficiency by $22.7 \mathrm{~g}$ of microbial CP per kilogram of true rumen digested OM.

Ruminal digestibility of $\mathrm{OM}$ and starch was not affected by treatments (Table 5). Decortication, how- 
Table 3. Intake and digested amount of nutrients in rumen, small intestine, hindgut, and total tract (kg/d unless otherwise noted)

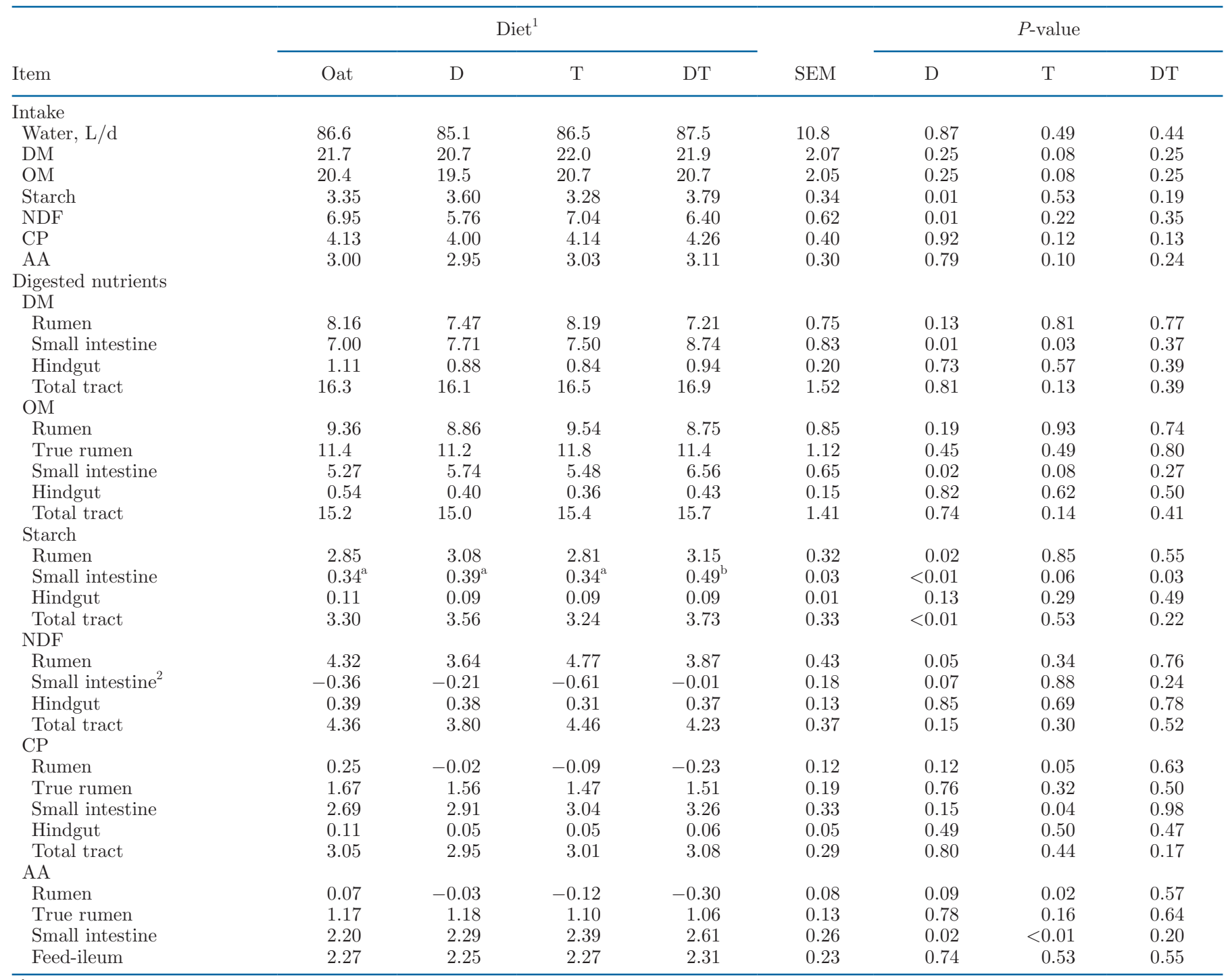

${ }^{\mathrm{a}, \mathrm{b}}$ Means in the same row with different superscripts differ $(P<0.05)$.

${ }^{1} \mathrm{D}=$ decorticated oat; $\mathrm{T}=$ toasted oat; $\mathrm{DT}=$ decorticated and toasted oat.

${ }^{2}$ Negative small intestine NDF digestibilities are mentioned in the discussion.

ever, increased $(P<0.01)$ small intestinal digestibility of DM, OM, and starch with a tendency $(P=0.07)$ for increasing small intestinal digestibility of AA. As shown in Table 6 , decortication increased $(P \leq 0.05)$ the digestibility of several individual AA (e.g., Ala, Glu, Met, and Pro). Toasting increased $(P=0.01)$ small intestinal digestibility of starch. Although toasting decreased $(P=0.03)$ ruminal digestibility of total AA, it did not influence small intestinal digestibility of individual AA. However, total-tract digestibility of $\mathrm{AA}$, as the AA disappearance between intake and ileal flow (feed-ileum), was decreased $(P=0.03)$ by toasting by $13.5 \mathrm{~g} / \mathrm{kg}$ of intake AA, calculated as the difference between the main effects (Table 5 ).
Composition of AA ( $\mathrm{g} / \mathrm{kg}$ of AA) in duodenal and ileal digesta is presented in Supplemental Table S4 (https://doi.org/10.3168/jds.2019-17142). Decortication increased $(P=0.03)$ His and slightly increased $(P$ $=0.06)$ Met proportion in duodenal AA. Toasting did not change His and Met proportions, but it decreased that of Lys $(P=0.04)$. Methionine in ileal AA composition tended $(P=0.07)$ to decrease by decortication and it increased $(P=0.01)$ by toasting.

\section{In Situ Study}

Decortication did not change rumen degradation parameters. However, toasting decreased water solubility 
and water-soluble fraction $(a)(P<0.01)$, with a consequent increase $(P<0.01)$ in the potentially degradable fraction $(b)$ for $\mathrm{CP}$ (Table 7$)$. Toasting reduced $(P<$ $0.01)$ degradation rate $(c)$ and $\mathrm{ED}$ of $\mathrm{CP}$ in the rumen by $0.46 \mathrm{~h}^{-1}$ and $310 \mathrm{~g} / \mathrm{kg}$ of $\mathrm{CP}$, respectively. Totaltract disappearance of $\mathrm{CP}$ increased $(P<0.01)$ due to both decortication and toasting, and it increased more for the decorticated and toasted oat than expected from the sole effects of decortication and toasting (interaction, $P=0.01)$. Decortication reduced $(P<0.01)$ SID of RUP, but toasting increased it $(P<0.01)$. The decorticated and toasted oat resulted in higher SID than the sole effects (interaction $P<0.001$ ).

\section{Rumen Fluid}

No differences related to the rumen $\mathrm{pH}$ and total short-chain fatty acid (SCFA) concentration were observed among treatments (Table 7). However, decortication decreased acetate $(P=0.03)$ and increased propionate $(P=0.05)$ proportion. Toasting tended to reduce acetate $(P=0.06)$ and isobutyrate $(P=0.07)$, and it reduced $(P=0.01)$ the isovalerate proportion in total SCFA. The diurnal pattern of rumen SCFA (results are not shown) was in accordance with the mean results presented in Table 8 .

\section{Milk Production}

Milk production and composition were not affected by treatments (results are not shown). On average, the following results were recorded: milk yield $(32.56 \pm 6.96$ $\mathrm{kg} / \mathrm{d}), \mathrm{ECM}$ yield $(33.1 \pm 7.45 \mathrm{~kg} / \mathrm{d})$, fat concentration $(41.0 \pm 7.96 \mathrm{~g} / \mathrm{kg}$ of milk), protein concentration (34.7 $\pm 3.35 \mathrm{~g} / \mathrm{kg}$ of milk), and lactose concentration (49.1 \pm $1.68 \mathrm{~g} / \mathrm{kg}$ of milk).

\section{Gas Exchange}

The net production of $\mathrm{CH}_{4}$ decreased with both decortication $(P=0.03)$ and toasting $(P=0.02)$ by 12.0 and $12.4 \mathrm{~L} / \mathrm{d}$, respectively (Table 9 ).

Table 4. Chemical composition of microbes and microbial flow to the duodenum (g/kg of microbial DM unless otherwise noted)

\begin{tabular}{|c|c|c|c|c|c|c|c|c|}
\hline \multirow[b]{2}{*}{ Item } & \multicolumn{4}{|c|}{ Diet $^{1}$} & \multirow[b]{2}{*}{ SEM } & \multicolumn{3}{|c|}{$P$-value } \\
\hline & Oat & $\mathrm{D}$ & $\mathrm{T}$ & DT & & $\mathrm{D}$ & $\mathrm{T}$ & $\mathrm{DT}$ \\
\hline \multicolumn{9}{|l|}{ Chemical composition } \\
\hline Ash & 186 & 189 & 206 & 192 & 9.34 & 0.56 & 0.20 & 0.32 \\
\hline $\mathrm{CP}$ & 568 & 559 & 539 & 545 & 8.53 & 0.79 & 0.03 & 0.40 \\
\hline AA & 440 & 429 & 423 & 422 & 4.56 & 0.22 & 0.03 & 0.27 \\
\hline Purine & 113 & 110 & 106 & 107 & 2.94 & 0.69 & 0.12 & 0.38 \\
\hline \multicolumn{9}{|l|}{ AA composition, $\mathrm{g} / \mathrm{kg}$ of $\mathrm{AA}$} \\
\hline Ala & 80.2 & 79.6 & 80.6 & 80.8 & 0.79 & 0.80 & 0.32 & 0.63 \\
\hline Arg & 50.6 & 51.3 & 50.1 & 50.4 & 0.45 & 0.16 & 0.05 & 0.57 \\
\hline Asp & 128 & 128 & 129 & 129 & 0.66 & 0.92 & 0.20 & 0.89 \\
\hline Cys & 11.6 & 11.5 & 11.5 & 11.4 & 0.09 & 0.19 & 0.19 & 0.95 \\
\hline Glu & 137 & 137 & 135 & 135 & 0.49 & 0.63 & $<0.01$ & 0.35 \\
\hline Gly & 59.1 & 59.0 & 59.3 & 59.5 & 0.16 & 0.55 & 0.01 & 0.22 \\
\hline His & 17.3 & 17.2 & 16.8 & 17.0 & 0.27 & 0.83 & 0.18 & 0.51 \\
\hline Ile & 66.2 & 66.1 & 66.9 & 66.0 & 0.34 & 0.07 & 0.26 & 0.13 \\
\hline Leu & 80.2 & 80.7 & 81.3 & 81.0 & 0.66 & 0.83 & 0.22 & 0.46 \\
\hline Lys & 82.1 & 81.8 & 81.7 & 82.2 & 0.69 & 0.75 & 0.96 & 0.37 \\
\hline Met & 24.3 & 24.0 & 24.0 & 24.4 & 0.34 & 0.79 & 0.97 & 0.20 \\
\hline Orn & 1.91 & 1.68 & 1.85 & 1.93 & 0.08 & 0.29 & 0.21 & 0.06 \\
\hline Phe & 52.6 & 53.4 & 53.7 & 52.9 & 0.62 & 0.99 & 0.57 & 0.14 \\
\hline Pro & 36.4 & 36.7 & 36.8 & 36.0 & 0.39 & 0.50 & 0.70 & 0.22 \\
\hline Ser & $47.3^{\mathrm{a}}$ & $48.4^{\mathrm{b}}$ & $47.9^{\mathrm{ab}}$ & $47.7^{\mathrm{ab}}$ & 0.20 & 0.05 & 0.88 & 0.01 \\
\hline Thr & 58.4 & 58.4 & 59.0 & 58.7 & 0.39 & 0.77 & 0.24 & 0.77 \\
\hline Val & 66.3 & 65.6 & 65.6 & 66.6 & 0.48 & 0.76 & 0.77 & 0.11 \\
\hline \multicolumn{9}{|l|}{ Microbial flow, $\mathrm{kg} / \mathrm{d}$} \\
\hline $\mathrm{OM}$ & 2.05 & 2.30 & 2.30 & 2.62 & 0.29 & $<0.01$ & $<0.01$ & 0.56 \\
\hline $\mathrm{CP}$ & 1.43 & 1.57 & 1.56 & 1.75 & 0.19 & 0.01 & 0.01 & 0.61 \\
\hline $\mathrm{AA}$ & 1.10 & 1.21 & 1.22 & 1.35 & 0.15 & 0.01 & 0.01 & 0.74 \\
\hline \multicolumn{9}{|l|}{ Microbial efficiency } \\
\hline $\mathrm{g}$ of $\mathrm{CP} / \mathrm{kg}$ of $\mathrm{OM}$ true digested in the rumen & 132 & 150 & 139 & 166 & 8.50 & 0.03 & 0.18 & 0.58 \\
\hline $\mathrm{g}$ of $\mathrm{AA} / \mathrm{kg}$ of $\mathrm{OM}$ true digested in the rumen & 102 & 115 & 109 & 129 & 6.87 & 0.03 & 0.14 & 0.61 \\
\hline
\end{tabular}

${ }^{\mathrm{a}, \mathrm{b}}$ Means in the same row with different superscripts differ $(P<0.05)$.

${ }^{1} \mathrm{D}=$ decorticated; $\mathrm{T}=$ toasted; $\mathrm{DT}=$ decorticated and toasted. 
Table 5. Rumen, intestine, hindgut, and total-tract digestibilities ${ }^{1}$ of different nutrients

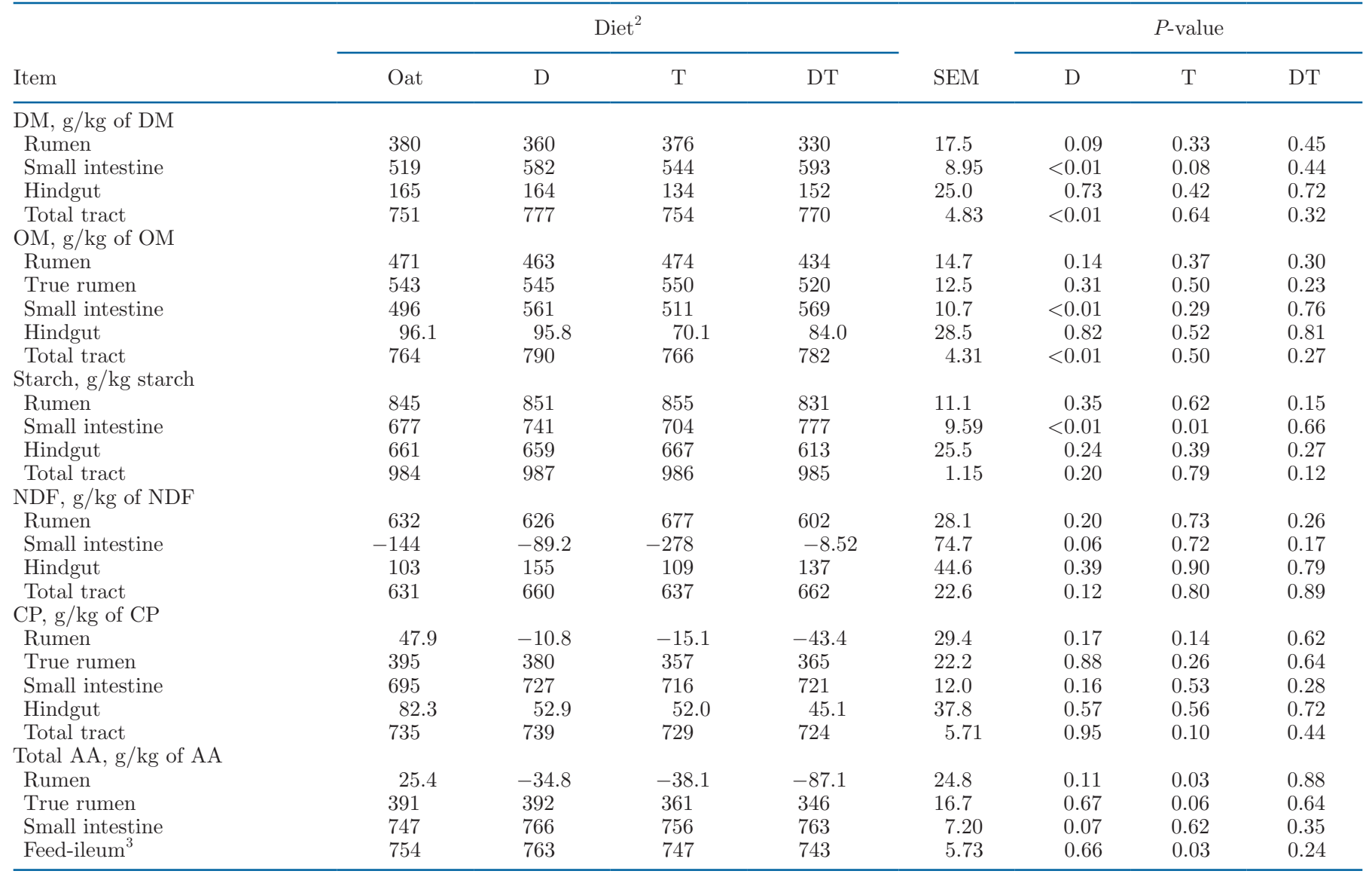

${ }^{1}$ Digestibility of nutrients in rumen, small intestine, hindgut, and total tract is reported in grams of digested nutrient per kilogram of nutrient intake, duodenal flow, ileal flow, and intake, respectively.

${ }^{2} \mathrm{D}=$ decorticated oat; $\mathrm{T}=$ toasted oat; DT $=$ decorticated and toasted oat.

${ }^{3}$ Total AA digestibility based on the intake and the ileal outflow.

Table 6. Small intestinal digestibility of AA ( $\mathrm{g} / \mathrm{kg}$ of duodenal AA flow)

\begin{tabular}{|c|c|c|c|c|c|c|c|c|}
\hline \multirow[b]{2}{*}{$\mathrm{AA}$} & \multicolumn{4}{|c|}{$\operatorname{Diet}^{1}$} & \multirow[b]{2}{*}{ SEM } & \multicolumn{3}{|c|}{$P$-value } \\
\hline & Oat & $\mathrm{D}$ & $\mathrm{T}$ & DT & & $\mathrm{D}$ & $\mathrm{T}$ & DT \\
\hline Ala & 686 & 711 & 703 & 714 & 8.91 & 0.05 & 0.25 & 0.39 \\
\hline Arg & 820 & 836 & 825 & 833 & 6.45 & 0.07 & 0.88 & 0.43 \\
\hline Asp & 740 & 759 & 749 & 757 & 6.88 & 0.09 & 0.64 & 0.44 \\
\hline Cys & 584 & 609 & 601 & 604 & 10.6 & 0.21 & 0.58 & 0.32 \\
\hline Glu & 733 & 755 & 745 & 753 & 6.99 & 0.05 & 0.47 & 0.32 \\
\hline Gly & 857 & 863 & 859 & 856 & 8.97 & 0.54 & 0.37 & 0.11 \\
\hline His & 732 & 754 & 740 & 751 & 8.10 & 0.08 & 0.78 & 0.51 \\
\hline Ile & 713 & 733 & 723 & 735 & 8.29 & 0.06 & 0.44 & 0.59 \\
\hline Leu & 745 & 763 & 754 & 760 & 7.68 & 0.12 & 0.66 & 0.41 \\
\hline Lys & 809 & 824 & 811 & 820 & 7.05 & 0.10 & 0.87 & 0.65 \\
\hline Met & 723 & 747 & 726 & 744 & 9.20 & 0.04 & 0.95 & 0.73 \\
\hline Orn & 481 & 543 & 527 & 533 & 27.7 & 0.23 & 0.52 & 0.31 \\
\hline Phe & 706 & 729 & 717 & 729 & 9.85 & 0.08 & 0.56 & 0.58 \\
\hline Pro & 677 & 707 & 691 & 701 & 8.62 & 0.05 & 0.65 & 0.27 \\
\hline Ser & 726 & 740 & 734 & 737 & 7.24 & 0.27 & 0.73 & 0.42 \\
\hline Thr & 694 & 715 & 710 & 717 & 7.55 & 0.11 & 0.28 & 0.37 \\
\hline Val & 734 & 756 & 747 & 758 & 7.49 & 0.06 & 0.36 & 0.48 \\
\hline
\end{tabular}

${ }^{1} \mathrm{D}=$ decorticated oat; $\mathrm{T}=$ toasted oat; $\mathrm{DT}=$ decorticated and toasted oat. 
Table 7. In situ degradability and small intestinal and total-tract digestibility of $\mathrm{CP}(\mathrm{g} / \mathrm{kg}$ of $\mathrm{CP})$

\begin{tabular}{|c|c|c|c|c|c|c|c|c|c|}
\hline Item $^{1}$ & \multicolumn{4}{|c|}{ Treatment } & SEM & \multicolumn{3}{|c|}{$P$-value } & Oat hull ${ }^{2}$ \\
\hline $\mathrm{SOL}$ & 98.5 & 94.5 & $0.0^{3}$ & 40.3 & & & & & 69.6 \\
\hline$p$ & 668 & 655 & 280 & 308 & & & & & 615 \\
\hline$a$ & 769 & 751 & 381 & 394 & 0.84 & 0.83 & $<0.01$ & 0.10 & $685 \pm 5.63$ \\
\hline SID & $323^{\mathrm{b}}$ & $209^{\mathrm{a}}$ & $836^{\mathrm{c}}$ & $872^{\mathrm{c}}$ & 7.81 & $<0.01$ & $<0.01$ & $<0.01$ & $486 \pm 1.86$ \\
\hline TTD & $932^{\mathrm{a}}$ & $938^{\mathrm{b}}$ & $934^{\mathrm{a}}$ & $946^{\mathrm{c}}$ & 0.80 & $<0.01$ & $<0.01$ & 0.01 & $897 \pm 0.37$ \\
\hline
\end{tabular}

${ }^{\mathrm{a}-\mathrm{c}}$ Means in the same row with different superscripts differ $(P<0.05)$.

${ }^{1} \mathrm{BS}=$ buffer solubility; $\mathrm{SOL}=$ water solubility; $p=$ particle loss calculated as $0 \mathrm{~h}$ loss from the bag minus SOL; $a=$ soluble fraction; $b=$ potentially degradable fraction; $c=$ rate of degradation of $b$ fraction $\left(\mathrm{h}^{-1}\right)$; ED = effective degradability of CP; SID = small intestinal disappearance of rumen undegraded protein $(\mathrm{g} / \mathrm{kg} \mathrm{RUP}) ; \mathrm{TTD}=$ total-tract disappearance $(\mathrm{g} / \mathrm{kg} \mathrm{CP})$.

${ }^{2}$ Mean \pm SD.

${ }^{3}$ Measured slightly negative $(-4.31 \mathrm{~g} / \mathrm{kg})$, reported as zero.

\section{DISCUSSION}

\section{Processing of Oat}

Decorticating of grains is a practical tool for increasing the digestible energy content of dairy cow diets without altering the forage-to-concentrate ratios (Yang et al., 1997; Wang et al., 2017). Decortication resulted in the expected changes in composition and in vitro digestibility (Panah et al., 2019). The composition of the removed oat hull showed that hulls are low in $\mathrm{CP}$ and high in NDF. Starch content was considerably higher $(221 \mathrm{~g} / \mathrm{kg}$ of $\mathrm{DM})$ than the feed table value $(130 \mathrm{~g} /$ $\mathrm{kg}$ of DM) for oat hull meal from the cereal industry (NorFor, 2019). The considerable starch concentration in the hulls indicated that the obtained hulls should be used as feed, for example, as substitute for straw in rations for dry cows and heifers. Earlier studies also showed that oat hull is mainly made up of low digestible cell wall (Decker et al., 2014), and fat and protein in the grain are mostly stored with the starch mass throughout the endosperm (Peterson and Wood, 1997). Therefore, decorticating exposes the digestible groat to ruminal fermentation.

On-farm toasting is used in practice in Denmark, and the oat used in this study was toasted on farm at $121^{\circ} \mathrm{C}$. Toasting increased DM concentration by approximately $100 \mathrm{~g} / \mathrm{kg}$ and reduced buffer solubility of CP by $117 \mathrm{~g} /$ $\mathrm{kg}$ of $\mathrm{CP}$ and in situ rumen protein degradability by $357 \mathrm{~g} / \mathrm{kg}$ of $\mathrm{CP}$ without decreasing total-tract mobile bag digestibility, showing that the toasting process performed as planned. This finding is in agreement with

Table 8. Rumen fermentation parameters

\begin{tabular}{|c|c|c|c|c|c|c|c|c|}
\hline Item & \multicolumn{4}{|c|}{ Diet $^{1}$} & SEM & \multicolumn{3}{|c|}{$P$-value } \\
\hline pH rumen & 6.32 & 6.33 & 6.37 & 6.32 & 0.12 & 0.50 & 0.60 & 0.32 \\
\hline \multicolumn{9}{|l|}{ SCFA, mol/100 mol of total SCFA } \\
\hline L-Lactate & 1.61 & 1.49 & 1.79 & 2.44 & 0.74 & 0.62 & 0.31 & 0.48 \\
\hline Acetate & 59.9 & 58.9 & 59.2 & 57.5 & 1.10 & 0.03 & 0.06 & 0.55 \\
\hline Isovalerate & 1.32 & 1.44 & 1.15 & 1.07 & 0.14 & 0.77 & 0.01 & 0.25 \\
\hline Valerate & 1.63 & 1.69 & 1.64 & 1.68 & 0.04 & 0.27 & 0.96 & 0.78 \\
\hline Caproate & 0.56 & 0.51 & 0.52 & 0.55 & 0.05 & 0.82 & 0.95 & 0.28 \\
\hline $\mathrm{NH}_{3}-\mathrm{N}, \mathrm{mmol} / \mathrm{L}$ & 9.28 & 9.53 & 8.84 & 9.22 & 0.62 & 0.53 & 0.45 & 0.89 \\
\hline Glucose, $\mathrm{mmol} / \mathrm{L}$ & 0.88 & 1.06 & 0.90 & 1.02 & 0.10 & 0.10 & 0.91 & 0.78 \\
\hline
\end{tabular}

${ }^{1} \mathrm{D}=$ decorticated oat; $\mathrm{T}=$ toasted oat; $\mathrm{DT}=$ decorticated and toasted oat.

${ }^{2}$ Short-chain fatty acids.

${ }^{3}$ Total lactate approximately 2 times L-lactate. 
Table 9. Dry matter intake during gas measurement and gas exchanges (d 17-22)

\begin{tabular}{|c|c|c|c|c|c|c|c|c|}
\hline Item $^{1}$ & \multicolumn{4}{|c|}{ Diet $^{2}$} & SEM & \multicolumn{3}{|c|}{$P$-value } \\
\hline DMI, $\mathrm{kg} / \mathrm{d}$ & 21.7 & 21.3 & 22.0 & 21.6 & 1.90 & 0.45 & 0.50 & 0.98 \\
\hline $\mathrm{CH}_{4}, \mathrm{~L} / \mathrm{kg}$ of $\mathrm{DMI}$ & 28.6 & 28.2 & 27.3 & 27.6 & 0.90 & 0.97 & 0.12 & 0.53 \\
\hline $\mathrm{CH}_{4}, \mathrm{~L} / \mathrm{kg}$ of TOMD & 63.4 & 59.8 & 59.0 & 63.5 & 2.66 & 0.86 & 0.90 & 0.16 \\
\hline $\mathrm{CH}_{4}, \mathrm{~L} / \mathrm{kg}$ of $\mathrm{ECM}$ & 20.7 & 17.9 & 18.3 & 17.8 & 1.34 & 0.19 & 0.30 & 0.36 \\
\hline $\mathrm{CH}_{4}: \mathrm{CO}_{2}$ ratio & 0.0846 & 0.0822 & 0.0824 & 0.0803 & 0.002 & 0.09 & 0.12 & 0.89 \\
\hline $\mathrm{O}_{2}$ consumption, $\mathrm{L} / \mathrm{d}$ & 6,550 & 6,540 & 6,527 & 6,680 & 508 & 0.48 & 0.56 & 0.43 \\
\hline
\end{tabular}

${ }^{1} \mathrm{TOMD}=$ true rumen $\mathrm{OM}$ digested; $\mathrm{CH}_{4}: \mathrm{CO}_{2}=$ the ratio of produced $\mathrm{CH}_{4}(\mathrm{~L} / \mathrm{d})$ to produced $\mathrm{CO}_{2}(\mathrm{~L} / \mathrm{d})$.

${ }^{2} \mathrm{D}=$ decorticated oat; $\mathrm{T}=$ toasted oat; $\mathrm{DT}=$ decorticated and toasted oat.

McNiven et al. (1995), who showed that heat treatment reduced ruminal degradation of $\mathrm{CP}$ in barley. Profiles of rumen protein degradation for toasted oat fit more poorly with the exponential function used to describe the degradation than profiles for oat due to a very high increase in degradability from 0 to $2 \mathrm{~h}$ incubation time. This finding indicates that toasting rendered some water soluble protein insoluble but still very quickly degradable.

\section{Digestion of CP and AA in the Small Intestine}

As decortication removes the physical barriers associated with the hull, we expected to find higher DMI with decortication. To the contrary, numerically lower DMI was observed, probably due to increased energy content of the diet (Yang et al., 1997). The numerically lower intake may have counterbalanced the increased $\mathrm{CP}$ content in oats caused by decortication, resulting in similar intake of CP and AA for the 4 diets. Similar milk production also reflected the similar intake of $\mathrm{CP}$ and AA.

In the present study, with similar intake of $\mathrm{CP}$ and AA among treatments, both toasting and decortication increased the microbial synthesis of $\mathrm{CP}$ and AA. The digested amount of AA in the small intestine was increased by both decortication and toasting. The availability of rapid fermentable carbohydrates along with an adequate degradable protein (Schwab and Broderick, 2017) increased microbial synthesis or microbial efficiency. Therefore, the higher microbial efficiency of protein synthesis due to decortication might be explained by higher availability of starch as an energy supply for rumen microbes. In agreement with our findings, Archimède et al. (1997) found an average of 23.6 $\pm 9.3 \mathrm{~g}$ of $\mathrm{N} / \mathrm{kg}$ of $\mathrm{OM}$ truly digested in the rumen for the microbial efficiency based on a database review involving 157 publications. In their review, higher inclusion of starch was associated with higher microbial efficiency until the point at which cellulolytic activity of rumen microbes started to be hampered. Moreover, it was previously reported that synchronization for rapid fermentation through provision of fast degradable starch and nitrogen increases the efficiency of microbial AA synthesis (NRC, 2001) and thereby leads to higher duodenal flow of microbial CP (Herrera-Saldana et al., 1990). Therefore, in the present study the increased starch intake upon decortication may have improved the synchronization between the digestible carbohydrate and $\mathrm{CP}$ and thereby the efficiency of microbial synthesis. Decortication did not change the rumen $\mathrm{pH}$ to the point at which cellulolytic activity could have been impaired because pH averaged $6.34 \pm 0.02$.

The slightly higher DMI due to toasting may partly explain the increasing effect of toasting on microbial synthesis of AA and CP. However, microbial efficiency was also numerically increased. Regardless of the increasing effect of toasting on total microbial $\mathrm{CP}$ and AA synthesis $(\mathrm{kg} / \mathrm{d})$, toasting reduced the concentration of CP and AA in microbial DM. In accordance, Hvelplund and Madsen (1993) reported that variations in the chemical composition of rumen microbes could be related to the diet to some extent; for example, energy, some nutrients, and the supply of rumen degradable protein and its quality contribute to this variation.

Methionine, Lys, and His are typically considered as the limiting AA for high-yielding dairy cattle (Schwab et al., 2005; Schwab and Broderick, 2017). The replacement of oat with decorticated, toasted, or decorticated and toasted oat did not change the Lys, Met, and His proportion in total microbial AA. However, the proportions of Arg, Glu, Gly, Ile, Orn, Phe, and Ser in total microbial AA changed due to the treatments. The microbial AA profile found in the present study was comparable to the values reported in the literature (Larsen et al., 2000; Johansen et al., 2018), with only minor variations in microbial AA composition due to the treatments. This difference in microbial AA compo- 
sition was possibly related to the variations in nutrient supply to the microbes, such as starch and rumen degradable AA (Hvelplund and Madsen, 1993; Johansen et al., 2017), because decortication increased starch intake and toasting reduced ruminal AA digestibility and ruminal in situ degradability of CP.

Both decortication and toasting decreased the Lys proportion in total AA intake. The similar Lys proportion in the duodenal flow, which was likely due to the high proportion of Lys in microbial AA, can offset the reducing effect of decortication on Lys intake. Toasting decreased His proportion, whereas Met proportion increased due to decortication and decreased upon toasting. However, regardless of these differences in the proportion of $\mathrm{AA}$ intake in the total $\mathrm{AA}$ among treatments, the trend of changes in AA composition of duodenal flow was to some extent different from the AA composition of the feed. Unaffected ruminal digestibility of Met ( $\mathrm{g} / \mathrm{kg}$ of AA intake) due to decortication along with its increased proportion in AA intake could explain the tendency of decortication to increase Met in duodenal AA. The increased Cys proportion in duodenal AA by toasting, despite its decrease in AA intake, reflects reduced ruminal digestibility of Cys due to toasting. For Lys, regardless of the fact that toasting significantly reduced its ruminal digestibility, its proportion in duodenal flow was reduced due to toasting. This outcome reflected the reduced proportion of Lys in AA intake due to toasting, possibly as a result of thermal damage. Decortication had only minor effects on ruminal digestibility of some AA (Ala, Asp, Lys, Phe, Ser, and Val), but toasting was shown to be a protective shield against ruminal digestion of AA, based on the results for Lys, Arg, Asp, Cys, Glu, Phe, Pro, Ser, and Val.

Additionally, the endogenous AA-N originating from glycoproteins in mucus, shed epithelial cells, and bile and digestive enzymes secreted in the abomasum and duodenum constitutes approximately $25 \%$ of total AA-N flow at the duodenum with a small intestinal digestibility of $62 \%$ (Larsen et al., 2000, 2001). In the present study, because the duodenal cannula was located after the bile duct entrance, a high proportion of Gly in the duodenal protein shows the presence of endogenous AA in the duodenal samples originating from bile. This finding is in agreement with Larsen et al. (2000), who reported that Gly is the most abundant AA originating from cow's bile.

Previous nylon bag studies showed that despite minor deviations, the proportion of AA in RUP is similar to that of the protein intake (Skórko-Sajko et al., 1994; Skiba et al., 1996; Hvelplund and Hesselholt, 1987); therefore, variation in the composition of AA intake is also expected to cause variation in the duodenal flow of AA. As a result, differences in the AA composition in the duodenal flow could mainly originate from AA composition of feed RUP and partially from variable contributions of microbial and endogenous AA. However, postruminal digestibility of AA in RUP may vary within the same protein source, depending on the treatment applied on the feedstuff because lower ruminal degradability of AA was reported to be associated with higher digestibility of RUP (Hvelplund and Madsen, 1993). Nevertheless, neither decortication nor toasting resulted in any decline in small intestinal digestibility of AA, which is in line with the reduced or tendency to be reduced ruminal digestibility of individual AA due to our treatments.

The effects of the applied treatments on changing the postruminal flow of $\mathrm{CP}$ and $\mathrm{AA}$ was highlighted by the different quantities of $\mathrm{CP}$ and $\mathrm{AA}$ digested in the small intestine. Along with increased supply of microbial AA at the duodenum, decortication also increased the daily digested amount of AA in the small intestine with a slight increase of the small intestinal digestibility of AA. The apparent small intestinal digestibility of the individual AA shows that decortication generally increased or tended to increase the digestibility of most AA. For instance, although decortication did not change the proportion of Ala, Glu, and Met in microbial AA, it increased both the intake of these AA and their small intestinal digestibility. This outcome could be due to the removal of the low digestible hull and its negative effect on intestinal digestibility (Welch et al., 1983). On the other hand, the lower digestibility of whole oat grain was attributed to the extensive ester cross-link bonds between polysaccharides and lignin in oat hull and its high fiber content (Yu et al., 2005; Kirkkari, 2008). The results of the mobile bag study showed that lower TTD of CP in the intact oat could be related to the low digestibility of hull protein in addition to its negligible CP concentration. Hvelplund (1985) also reported a lower small intestinal digestibility of RUP in some feedstuffs due to higher proportion of cell wall bound nitrogen content. Another study likewise suggested a negative correlation between the fiber content and nutrient digestibility (Wang et al., 2017).

The increased amount of digested AA $(\mathrm{kg} / \mathrm{d})$ due to toasting could be explained by increased duodenal flow of AA with unaffected small intestinal digestibility. Increased duodenal flow of CP and AA, caused by toasting, derived from the reduced ruminal digestibility and the digested amount of AA and the increased microbial AA synthesis. In accordance, heat treatment has been used to reduce ruminal degradation of feed proteins and increasing the supply of dietary protein at the duodenum (McNiven et al., 1995; Schwab, 1995). This effect is induced by denaturation of proteins and 
formation of protein-carbohydrate (Maillard reactions) cross-links via a reaction between $\varepsilon$-amino groups of AA and carbonyl group of reducing sugars, which reduces protein degradability in the rumen (Kung and Rode, 1996; NRC, 2001; Lund et al., 2004). McNiven et al. (1994) showed a decreased ruminal and total-tract digestibility of $\mathrm{CP}$ for oat when it was heat treated at $168^{\circ} \mathrm{C}$. In the present study, the feed-ileum digestibility of AA was decreased on average by $13.5 \mathrm{~g} / \mathrm{kg}$ of AA intake due to toasting, indicating minor heat damage to $\mathrm{AA}$ in the feed. However, toasting at $121^{\circ} \mathrm{C}$ did not influence the small intestinal digestibility of $\mathrm{CP}$ and individual AA, and it increased the amount of digested AA in the small intestine. Therefore, the applied heat in the present study did not overprotect $\mathrm{CP}$ and $\mathrm{AA}$ for small intestinal digestibility, and toasting of oat caused a shift in the site of AA digestion from the rumen to the small intestine. Chowdhury et al. (2018) showed that Lys is one of the most heat-sensitive AA. Data on the Lys digestibility for diets with toasted oat were similar to the other treatments, which indicates that toasting oat at $121^{\circ} \mathrm{C}$ did not overprotect the CP.

Toasting reduced in situ degradability, and in situ results quantitatively confirmed the flow of $\mathrm{CP}$ at the duodenum for the in vivo study. Mobile bag results for total-tract CP digestibility showed a slight increase, whereas feed-ileum digestibility of AA showed a slight decrease. The increased SID due to toasting was due to the reduced ED and equivalent increased RUP. Hvelplund et al. (1992) reported that lower ruminal degradability of $\mathrm{CP}$ was associated with higher small intestinal digestibility of RUP. This finding might also explain the lower small intestinal digestibility of $\mathrm{CP}$ due to decortication because decortication numerically increased ED. Total-tract disappearance (mobile bags) of CP was statistically increased by both decortication and toasting, but the difference was numerically small.

\section{Digestibility of Other Nutrients}

Based on a meta-analysis of in vivo studies in dairy cows, Moharrery et al. (2014) showed a negative correlation between starch intake and its ruminal digestibility in corn, wheat, barley, and sorghum, mainly due to its positive correlation with DMI resulting in an increased passage rate. In agreement with that study, the constant DMI and digested amount of DM in the rumen among our treatments indicate a rather constant passage rate due to treatments. Therefore, the increased starch intake due to decortication and increased starch concentration in feed DM did not influence ruminal starch digestibility. In our study, higher small intestinal and total-tract digestibility of $\mathrm{DM}$ and $\mathrm{OM}$ and higher small intestinal digestibility of starch in decorticated oat are presumably related to the lower fiber concentration. The increased intake of starch due to decortication, along with the unaffected ruminal digestibility of starch, could also explain the increased digested starch in the small intestine as well as its increased small intestinal digestibility. This possibility is in line with Moharrery et al. (2014), who reported a higher small intestinal digestion of starch due to increased flow of starch at the duodenum. Toasting slightly increased DMI without influencing the starch intake and ruminal digestibility of starch in the present study. It was previously reported that toasting at $130^{\circ} \mathrm{C}$ decreased ruminal degradability of starch in fava beans, peas, and lupins (Goelema et al., 1998). However, the insignificant influence of toasting on ruminal digestibility of starch in this study could be due to the different applied temperature (i.e., 121 vs. $130^{\circ} \mathrm{C}$ ), starch structures in different grains, and the variable influence of heat treatment on different grains (Theurer, 1986). Although the in situ digestibility of lost particles was previously assumed to be similar to the particles remaining in the bag (Hvelplund and Weisbjerg, 2000), the interpretation of in situ observations in the case of oat grains must be done with caution. Particle loss for DM and CP is substantial in oat (Panah et al., 2019). Therefore, due to the methodology of in situ evaluation, the in vivo ruminal starch digestibility cannot be explained by reduced DM and CP particle loss in situ due to toasting. Regardless of unaffected starch intake and ruminal digestibility of starch due to toasting, toasting increased small intestinal digestibility of starch in oat and it was within the range reported by Moharrery et al. (2014). The increased small intestinal digestibility of starch by toasting might be due to the structural changes induced to the starch granules, making them more susceptible to small intestinal digestion (Theurer, 1986).

Consistent with other studies (Lund et al., 2007; Brask et al., 2013b; Olijhoek et al., 2016; Johansen et al., 2017), the small intestinal digestibility of NDF was negative for all diets, possibly due to problems with representative sampling from intestinal cannulas with respect to the fiber fraction (Olijhoek et al., 2016).

\section{Rumen Fluid}

Ruminal $\mathrm{pH}$ and total VFA concentration were not affected by treatments, which fits with almost the same amount of fermented OM being found. Although ruminal pH was not affected, the results of the present study showed slightly lower acetate production along with a slightly higher propionate proportion due to decortication. This result reflected the lower intake of NDF and the higher intake of starch due to decortication. It was 
previously reported that a higher intake of NDF can be expected to enhance acetic acid production, and higher starch intake enhances propionate production in the rumen (Brask et al., 2013a). The reducing effect of toasting on ruminal degradability of AA was in accordance with the reduced proportions of isovalerate and isobutyrate in rumen SCFA because rumen branched-chain SCFA originates from the degradation of branched-chain AA (Johansen et al., 2017). This is in agreement with McNiven et al. (1995), who reported a lower isovaleric acid in the ruminal fluid of the cows fed heat-treated barley due to recorded lower ruminal degraded AA. The $\mathrm{NH}_{3}-\mathrm{N}$ concentration was unaffected by treatments, although we had expected a lower $\mathrm{NH}_{3}-\mathrm{N}$ due to toasting because toasting decreased the ruminal digestibility of AA and increased microbial synthesis.

\section{Methane Production}

As expected, decortication reduced $\mathrm{CH}_{4}$ production (L/d) due to an increased proportion of easily digestible carbohydrates, reduced NDF, and increased proportion of propionate in total SCFA (Boadi et al., 2004; Brask et al., 2013a); however, opposite to our expectation, decortication did not reduce $\mathrm{CH}_{4}$ production per kilogram of DM intake. Toasting also reduced daily $\mathrm{CH}_{4}$ production $(\mathrm{L} / \mathrm{d})$, possibly due to the tendency for decreased acetate proportion and numerically increased propionate proportion due to toasting. However, the results are difficult to interpret because OM digested in the rumen was similar.

\section{CONCLUSIONS}

Decortication increased the daily intake of starch. Small intestinal digestibility of starch increased by both decortication and toasting. Toasting increased small intestinal digested CP. Both decortication and toasting increased the amount of AA digested in the small intestine, decortication mainly due to increased efficiency of microbial protein synthesis and toasting due to decreased rumen degradation of feed protein. Both decortication and toasting reduced $\mathrm{CH}_{4}$ production per day but not per kilogram of DM intake.

\section{ACKNOWLEDGMENTS}

We thank the Danish Milk Levy Fund (Mælkeafgiftsfonden, Aarhus, Denmark) for its financial support, Visti Møller (Gl. Buurholt ApS, Brønderslev, Denmark) for performing decortication, and Jens Peter Jeppesen (Lemvig, Denmark) for toasting of the oat. We also thank department staff Torkild N. Jakobsen, Amin T. Aljundi, laboratory technicians, and barn personnel for their dedicated participation. The authors have not stated any conflicts of interest.

\section{REFERENCES}

Åkerlind, M., M. Weisbjerg, T. Eriksson, R. Tøgersen, P. Udén, B. L. Ólafsson, O. M. Harstad, and H. Volden. 2011. Feed analyses and digestion methods. Pages 41-54 in NorFor-The Nordic Feed Evaluation System. H. Volden, ed. Wageningen Academic Publishers, Wageningen, the Netherlands.

Archimède, H., D. Sauvant, and P. Schmidely. 1997. Quantitative review of ruminal and total tract digestion of mixed diet organic matter and carbohydrates. Reprod. Nutr. Dev. 37:173-189. https: //doi.org/10.1051/rnd:19970205.

Bach Knudsen, K. E., P. Åman, and B. O. Eggum. 1987. Nutritive value of Danish-grown barley varieties, I, carbohydrates and other major constituents. J. Cereal Sci. 6:173-186. https://doi.org/10 .1016/S0733-5210(87)80053-X.

Bates, D., M. Mächler, B. Bolker, and S. Walker. 2014. Fitting linear mixed-effects models using lme4. J. Stat. Soft. 67:1-48.

Biel, W., K. Bobko, and R. Maciorowski. 2009. Chemical composition and nutritive value of husked and naked oats grain. J. Cereal Sci. 49:413-418. https://doi.org/10.1016/j.jcs.2009.01.009.

Blanco-Penedo, I., N. Fall, and U. Emanuelson. 2012. Effects of turning to $100 \%$ organic feed on metabolic status of Swedish organic dairy cows. Livest. Sci. 143:242-248. https://doi.org/10.1016/j .livsci.2011.09.023.

Boadi, D., C. Benchaar, J. Chiquette, and D. Massé. 2004. Mitigation strategies to reduce enteric methane emissions from dairy cows: Update review. Can. J. Anim. Sci. 84:319-335. https://doi.org/10 .4141/A03-109.

Brask, M., P. Lund, A. L. F. Hellwing, M. Poulsen, and M. R. Weisbjerg. 2013a. Enteric methane production, digestibility and rumen fermentation in dairy cows fed different forages with and without rapeseed fat supplementation. Anim. Feed Sci. Technol. 184:67-79. https://doi.org/10.1016/j.anifeedsci.2013.06.006.

Brask, M., P. Lund, M. R. Weisbjerg, A. L. F. Hellwing, M. Poulsen, M. K. Larsen, and T. Hvelplund. 2013b. Methane production and digestion of different physical forms of rapeseed as fat supplements in dairy cows. J. Dairy Sci. 96:2356-2365. https://doi.org/ $10.3168 /$ jds.2011-5239

Brask, M., M. R. Weisbjerg, A. L. F. Hellwing, A. Bannink, and P. Lund. 2015. Methane production and diurnal variation measured in dairy cows and predicted from fermentation pattern and nutrient or carbon flow. Animal 9:1795-1806. https://doi.org/10.1017/ S1751731115001184.

Chowdhury, M. R., S. Lashkari, S. K. Jensen, M. Ambye-Jensen, and M. R. Weisbjerg. 2018. Effects of heat treatment of green protein on in situ protein disappearance and in vitro fatty acid biohydrogenation. J. Agric. Food Chem. 66:8169-8178. https://doi.org/10 $.1021 /$ acs.jafc.8b02176.

Danish Agriculture and Food Council. 2019. Organic milk and beef. Accessed May 28, 2019. https://lf.dk/viden-om/oekologi/ okologiske-produkter/maelk-og-oksekoed. (In Danish).

Decker, E. A., D. J. Rose, and D. Stewart. 2014. Processing of oats and the impact of processing operations on nutrition and health benefits. Br. J. Nutr. 112(Suppl. 2):S58-S64.

European Commission. 1998. Commission Directive 98/64/EC of 3 September 1998: Establishing community methods of analysis for the determination of amino-acids, crude oils and fats, and olaquindox in feedingstuffs, and amending Directive 71/393/EEC. Off. J. L257:0014-0028.

Fall, N., Y. T. Grohn, K. Forslund, B. Essen-Gustafsson, R. Niskanen, and U. Emanuelson. 2008. An observational study on early-lactation metabolic profiles in Swedish organically and conventionally managed dairy cows. J. Dairy Sci. 91:3983-3992. https://doi.org/ 10.3168/jds.2008-1099.

Garleb, K. A., L. D. Bourquin, J. T. Hsu, G. W. Wagner, S. J. Schmidt, and J. G. C. Fahey. 1991. Isolation and chemical analyses 
of nonfermented fiber fractions of oat hulls and cottonseed hulls. J. Anim. Sci. 69:1255-1271. https://doi.org/10.2527/1991.6931255x.

Goelema, J. O., M. A. M. Spreeuwenberg, G. Hof, A. F. B. van der Poel, and S. Tamminga. 1998. Effect of pressure toasting on the rumen degradability and intestinal digestibility of whole and broken peas, lupins and faba beans and a mixture of these feedstuffs. Anim. Feed Sci. Technol. 76:35-50. https://doi.org/10.1016/S0377 -8401(98)00212-0.

Hansen, B. 1989. Determination of nitrogen as elementary N, an alternative to Kjeldahl. Acta Agric. Scand. 39:113-118. https://doi .org/10.1080/00015128909438504.

Hellwing, A. L. F., P. Lund, M. R. Weisbjerg, M. Brask, and T. Hvelplund. 2012. Technical note: Test of a low-cost and animal-friendly system for measuring methane emissions from dairy cows. J. Dairy Sci. 95:6077-6085. https://doi.org/10.3168/jds.2012-5505.

Herrera-Saldana, R., R. Gomez-Alarcon, M. Torabi, and J. T. Huber. 1990. Influence of synchronizing protein and starch degradation in the rumen on nutrient utilization and microbial protein synthesis. J. Dairy Sci. 73:142-148. https://doi.org/10.3168/jds.S0022 -0302(90)78657-2.

Hvelplund, T. 1985. Digestibility of rumen microbial protein and undegraded dietary protein estimated in the small intestine of sheep and by in sacco procedure. Acta Agric. Scand. Suppl. 25:132-144.

Hvelplund, T., and M. Hesselholt. 1987. Digestibility of individual amino acids in rumen microbial protein and undegraded dietary protein in the small intestine of sheep. Acta Agric. Scand. 37:469477. https://doi.org/10.1080/00015128709436578.

Hvelplund, T., and J. Madsen. 1993. Protein systems for ruminants. Icel. Agric. Sci. 7:21-36.

Hvelplund, T., and M. Weisbjerg. 2000. In situ techniques for the estimation of protein degradability and postrumen availability. Pages 233-258 in Forage Evaluation in Ruminant Nutrition. D. I. Givens, E. Oven, R. F. E. Axford, and H. M. Omed, ed. CAB International, Wallingford, UK.

Hvelplund, T., M. R. Weisbjerg, and L. S. Andersen. 1992. Estimation of the true digestibility of rumen undegraded dietary protein in the small intestine of ruminants by the mobile bag technique. Acta Agric. Scand. Sect. A Anim. Sci. 42:34-39.

Johansen, M., A. L. F. Hellwing, P. Lund, and M. R. Weisbjerg. 2017. Metabolisable protein supply to lactating dairy cows increased with increasing dry matter concentration in grass-clover silage. Anim. Feed Sci. Technol. 227:95-106. https://doi.org/10.1016/j .anifeedsci.2017.02.018.

Johansen, M., P. Lund, and M. R. Weisbjerg. 2018. Amino acid profile of metabolisable protein in lactating dairy cows is affected by dry matter concentration in grass-clover silage. Anim. Feed Sci. Technol. 237:166-174. https://doi.org/10.1016/j.anifeedsci.2018 .01 .002 .

Kirkkari, A.-M. 2008. Comparative economic analysis for production of naked vs. conventional oat. Acta Agric. Scand. B Soil Plant Sci. 58:305-313. https://doi.org/10.1080/09064710701718296.

Kristensen, N. B., A. Danfær, V. Tetens, and N. Agergaard. 1996. Portal recovery of intraruminally infused short-chain fatty acids in sheep. Acta Agric. Scand. A Anim. Sci. 46:26-38.

Kung, L. Jr., and L. M. Rode. 1996. Amino acid metabolism in ruminants. Anim. Feed Sci. Technol. 59:167-172. https://doi.org/10 .1016/0377-8401(95)00897-7.

Larsen, M., T. G. Madsen, M. R. Weisbjerg, T. Hvelplund, and J. Madsen. 2000. Endogenous amino acid flow in the duodenum of dairy cows. Acta Agric. Scand. A Anim. Sci. 50:161-173. https:// doi.org/10.1080/090647000750014296.

Larsen, M., T. G. Madsen, M. R. Weisbjerg, T. Hvelplund, and J. Madsen. 2001. Small intestinal digestibility of microbial and endogenous amino acids in dairy cows. J. Anim. Physiol. Anim. Nutr. (Berl.) 85:9-21. https://doi.org/10.1046/j.1439-0396.2001.00297.x.

Lashkari, S., O. Azizi, and H. Jahani-Azizabadi. 2015. Effects of different processing methods of flaxseed on ruminal degradability and in vitro post-ruminal nutrient disappearance. Arch. Anim. Nutr. 69:177-186. https://doi.org/10.1080/1745039X.2015.1034520.

Lund, P., M. R. Weisbjerg, and T. Hvelplund. 2003. Effect of forage type and supplementation on microbial synthesis and efficiency in the rumen of dairy cows. Pages 627-630 in Progress in Research on Energy and Protein Metabolism. EAAP Publication 109. Wageningen Academic Publishers, Wageningen, the Netherlands.

Lund, P., M. R. Weisbjerg, T. Hvelplund, and K. E. Bach Knudsen. 2007. Determination of digestibility of different forages in dairy cows using indigestible NDF as marker. Acta Agric. Scand. A Anim. Sci. 57:16-29. https://doi.org/10.1080/09064700701440421. Lund, P., M. R. Weisbjerg, and T. Kristensen. 2004. The effect of heat treatment on degradability and microbial synthesis of protein in the rumen. Anim. Feed Sci. Technol. 13(Suppl. 1):143-146. https: //doi.org/10.22358/jafs/73762/2004.

McNiven, M. A., R. M. G. Hamilton, P. H. Robinson, and J. W. deLeeuw. 1994. Effect of flame roasting on the nutritional quality of common cereal grains for non-ruminants and ruminants. Anim. Feed Sci. Technol. 47:31-40. https://doi.org/10.1016/0377 -8401(94)90157-0.

McNiven, M. A., M. R. Weisbjerg, and T. Hvelplund. 1995. Influence of roasting or sodium hydroxide treatment of barley on digestion in lactating cows. J. Dairy Sci. 78:1106-1115. https://doi.org/10 .3168/jds.S0022-0302(95)76727-3.

Mertens, D. R. 2002. Gravimetric determination of amylase-treated neutral detergent fiber in feeds with refluxing in beakers or crucibles: Collaborative study. J. AOAC Int. 85:1217-1240.

Moe, P., and H. Tyrrell. 1979. Methane production in dairy cows. J. Dairy Sci. 62:1583-1586. https://doi.org/10.3168/jds.S0022 $-0302(79) 83465-7$.

Moharrery, A., M. Larsen, and M. R. Weisbjerg. 2014. Starch digestion in the rumen, small intestine, and hind gut of dairy cows- $\mathrm{A}$ meta-analysis. Anim. Feed Sci. Technol. 192:1-14. https://doi.org/ 10.1016/j.anifeedsci.2014.03.001.

Møller, E., P. E. Andersen, and N. Witt. 1989. En sammenligning af in vitro opløselighed in vivo fordøjelighed af organisk stof i grovfoder. Beretning fra Fællesudvalget for Statens Planteavls-og Husdyrbrugsfors $\varnothing$, Denmark. 13:23 pp. (In Danish).

Myers, W. D., P. Ludden, V. Nayigihugu, and B. Hess. 2004. A procedure for the preparation and quantitative analysis of samples for titanium dioxide. J. Anim. Sci. 82:179-183. https://doi.org/10 $.2527 / 2004.821179 x$.

Nocek, J. E. 1988. In situ and other methods to estimate ruminal protein and energy digestibility: A review. J. Dairy Sci. 71:2051-2069. https://doi.org/10.3168/jds.S0022-0302(88)79781-7.

NorFor. 2019. NorFor feed table. Accessed October 17, 2019. http:// feedstuffs.norfor.info/.

NRC. 2001. Nutrient Requirements of Dairy Cattle. 7th rev. ed. National Academy Press, Washington, DC.

Olijhoek, D. W., A. L. F. Hellwing, M. Brask, M. R. Weisbjerg, O. Højberg, M. K. Larsen, J. Dijkstra, E. J. Erlandsen, and P. Lund. 2016. Effect of dietary nitrate level on enteric methane production, hydrogen emission, rumen fermentation, and nutrient digestibility in dairy cows. J. Dairy Sci. 99:6191-6205. https://doi.org/10 .3168/jds.2015-10691.

Ørskov, E. R., and I. McDonald. 1979. The estimation of protein degradability in the rumen from incubation measurements weighted according to rate of passage. J. Agric. Sci. 92:499-503. https://doi .org/10.1017/S0021859600063048.

Oste, R. E., A. Dahlqvist, H. Sjoestroem, O. Noren, and R. Miller. 1986. Effect of Maillard reaction products on protein digestion. In vitro studies. J. Agric. Food Chem. 34:355-358. https://doi.org/ 10.1021/jf00068a051.

Panah, F. M., S. Lashkari, and M. R. Weisbjerg. 2019. Effect of oat decortication on chemical composition, in vitro digestibility and in situ degradability. J. Anim. Physiol. Anim. Nutr. (Berl.) https:// doi.org/10.1111/jpn.13217.

Peterson, D. M., and D. F. Wood. 1997. Composition and structure of high-oil oat. J. Cereal Sci. 26:121-128. https://doi.org/10.1006/ jers.1996.0111.

Qi, X., L. Zhu, C. Wang, H. Zhang, L. Wang, and H. Qian. 2017. Development of standard fingerprints of naked oats using chromatography combined with principal component analysis and cluster analysis. J. Cereal Sci. 74:224-230. https://doi.org/10.1016/j.jcs .2017 .02 .009 . 
R Core Team. 2018. R: A Language and Environment for Statistical Computing. R Foundation for Statistical Computing, Vienna, Austria. http://www. R-project. org.

Rudemo, M., S. Bech-Andersen, and V. Mason. 1980. Hydrolysate preparation for amino acid determinations in feed constituents: 5. The influence of hydrolysis time on amino acid recovery. Z Tierphysiol. Tierernäh. Futtermittelkd. 43:27-34. https://doi.org/ 10.1111/j.1439-0396.1980.tb00603.x.

Salo, M.-L., and K. Kotilainen. 1970. On the carbohydrate composition and nutritive value of some cereals. Agric. Food Sci. 42:21-29. https://doi.org/10.23986/afsci.71752.

Savari, M., M. Khorvash, H. Amanlou, G. R. Ghorbani, E. Ghasemi, and M. Mirzaei. 2018. Effects of rumen-degradable protein:rumen -undegradable protein ratio and corn processing on production performance, nitrogen efficiency, and feeding behavior of Holstein dairy cows. J. Dairy Sci. 101:1111-1122. https://doi.org/10.3168/ jds.2017-12776.

Schwab, C., P. Huhtanen, C. Hunt, and T. Hvelplund. 2005. Nitrogen requirements of cattle. Pages 13-70 in Nitrogen and Phosphorus Nutrition of Cattle. CAB International, Wallingford, UK.

Schwab, C. G. 1995. Protected proteins and amino acids for ruminants. Pages 115-141 in Biotechnology in Animal Feeds and Animal Feeding. R. J. Wallace and A. Chesson, ed. VCH Press, Weinheim, Germany.

Schwab, C. G., and G. A. Broderick. 2017. A 100-year review: Protein and amino acid nutrition in dairy cows. J. Dairy Sci. 100:1009410112. https://doi.org/10.3168/jds.2017-13320.

Schürch, A., L. Lloyd, and E. Crampton. 1950. The use of chromic oxide as an index for determining the digestibility of a diet. J. Nutr. 41:629-636.

Scollan, N., S. Padel, N. Halberg, J. Hermansen, P. Nicholas, M. Rinne, R. Zanoli, W. Zollitsch, and L. Lauwers. 2017. Organic and low-input dairy farming: Avenues to enhance sustainability and competitiveness in the EU. EuroChoices (Uckfield) 16:40-45. https://doi.org/10.1111/1746-692X.12162.

Sjaunja, L. O., L. Baevre, L. Junkkarinen, J. Pedersen, and J. Setälä 1990. A Nordic proposition for an energy corrected milk (ECM) formula. Pages 156-157 in 27th Session of the International Committee for Recording the Productivity of Milk Animals (ICRPMA). European Association of Animal Production Publications.

Skiba, B., M. Weisbjerg, and T. Hvelplund. 1996. Rumen and total intestinal tract digestibility of protein and amino acids from different roughages determined in situ. J. Anim. Feed Sci. 5:347-363. https://doi.org/10.22358/jafs/69614/1996.

Skórko-Sajko, H., T. Hvelplund, and M. R. Weisbjerg. 1994. Rumen degradation and intestinal digestibility of amino acids in different roughages estimated by nylon bag techniques. J. Anim. Feed Sci. 3:1-10. https://doi.org/10.22358/jafs/69813/1994.

Stoldt, W. 1952. Vorschlag zur vereinheitlichung der fettbestimmung in lebensmitteln. Fette und Seifen 54:206-207. https://doi.org/10 .1002/lipi.19520540406.

Theurer, C. B. 1986. Grain processing effects on starch utilization by ruminants. J. Anim. Sci. 63:1649-1662. https://doi.org/10.2527/ jas1986.6351649x.
Thode, S. 1999. Bestemmelse af purinderivater (allantoin, urinsyre, hypoxanthin og xanthin) samt kreatinin i urin hos kvæg ved anvendelse af HPLC (In Danish). Intern Rapport no. 127. Danmarks JordbrugsForskning, Foulum, Denmark.

Tilley, J. M. A., and R. A. Terry. 1963. A two-stage technique for the in vitro digestion of forage crops. Grass Forage Sci. 18:104-111. https://doi.org/10.1111/j.1365-2494.1963.tb00335.x.

Volden, H. 2011. NorFor, the Nordic Feed Evaluation System. EAAP Scientific Series, Vol. 130. Wageningen Academic Publishers, Wageningen, the Netherlands.

Wang, H. L., M. Shi, X. Xu, L. Pan, L. Liu, and X. S. Piao. 2017. Partial dehulling increases the energy content and nutrient digestibility of barley in growing pigs. Asian-Australas. J. Anim. Sci. 30:562-568. https://doi.org/10.5713/ajas.16.0429.

Weisbjerg, M., and T. Hvelplund. 1993. Bestemmelse af nettoenergiindhold (FEK) i foder til kvæg. Forskningsrapport Nr. 3. Natl. Inst. Anim. Sci., Foulum, Denmark.

Welch, R. W., M. V. Hayward, and D. I. H. Jones. 1983. The composition of oat husk and its variation due to genetic and other factors. J. Sci. Food Agric. 34:417-426. https://doi.org/10.1002/ jsfa. 2740340502.

Willer, H., D. Schaack, and J. Lernoud. 2019. Organic farming and market development in Europe and the European Union. Pages 217-254 in The World of Organic Agriculture-Statistics and Emerging Trends. Research Institute of Organic Agriculture FiBL and IFOAM-Organics International, Bonn, Germany.

Yang, W. Z., K. A. Beauchemin, K. M. Koenig, and L. M. Rode. 1997. Comparison of hull-less barley, barley, or corn for lactating cows: Effects on extent of digestion and milk production. J. Dairy Sci. 80:2475-2486. https://doi.org/10.3168/jds.S0022-0302(97)76200 $-3$.

Yu, P., J. J. McKinnon, and D. A. Christensen. 2005. Improving the nutritional value of oat hulls for ruminant animals with pretreatment of a multienzyme cocktail: In vitro studies. J. Anim. Sci. 83:1133-1141. https://doi.org/10.2527/2005.8351133x.

Zinn, R. A., and F. N. Owens. 1986. A rapid procedure for purine measurement and its use for estimating net ruminal protein synthesis. Can. J. Anim. Sci. 66:157-166. https://doi.org/10.4141/ cjas86-017.

\section{ORCIDS}

Farhad M. Panah (1) https://orcid.org/0000-0002-6623-1528

Saman Lashkari ๑ https://orcid.org/0000-0002-2033-7837

Anne Louise Frydendahl Hellwing @ \ttps://orcid.org/0000-0002-2881

$-399 \mathrm{X}$

Mogens Larsen () https://orcid.org/0000-0003-3767-0908

Martin Riis Weisbjerg @ https://orcid.org/0000-0002-6514-9186 